\title{
3. LOWER CRETACEOUS CALCAREOUS NANNOPLANKTON FROM DSDP HOLE 397A (NORTHWEST AFRICAN MARGIN)
}

\author{
Frank H. Wind, ${ }^{1}$ Antarctic Marine Geology Research Facility, Department of Geology, \\ Florida State University, Tallahassee, Florida \\ and \\ Pavel Čepek, Federal Institute for Geosciences and Natural Resources (Bundesanstalt für Geowissenschaften \\ und Rohstoffe), Hannover, Federal Republic of Germany
}

\section{INTRODUCTION}

Deep Sea Drilling Project Leg 47A recovered midLower Cretaceous sediment from Hole 397A in the eastern Atlantic Ocean near Cape Bojador (lat $26^{\circ} 50.7^{\prime} \mathrm{N}$, long $15^{\circ} 10.8^{\prime} \mathrm{W}$ ) (see Figure 1). Two sites in fairly close proximity to Site 397 recovered coeval sediment, but with poorer preservation; DSDP Leg 41, Site 367, in the Cape Verde Basin, and Leg 41, Site 370, in a deep basin off the coast of Morocco.

Lower Cretaceous sediment recovered in 19 cores (397A-34 through 397A-52) is overlain by a thick Neogene section, with the boundary between the lower Miocene Discoaster druggii (NN 2) Zone and the Lower Cretaceous placed between Samples 397A-34-1, $70 \mathrm{~cm}$ and $397 \mathrm{~A}-34-1,102 \mathrm{~cm}$, at approximately 1300 meters sub-bottom. The hiatus separating these sediments of radically differing ages represents an interval of between 100 and 105 million years.

Sediments in the 153 meters of Lower Cretaceous section are typically finely laminated, dark gray quartzose mudstone, often containing abundant siderite and minor dolomite. Siderite and dolomite are often concentrated in thin fine-grained intercalations. Both the abundance and quality of preservation of calcareous nannoplankton varies greatly from sample to sample. When the nannoplankton are abundant and well preserved, the flora is far more diverse than any Lower Cretaceous previously reported. In addition to the presence of many new species, only some of which are described in this previously named taxa reveals morphological features neither described nor illustrated in existing literature. Species recognized in Hole 397A samples are listed in Table 1.

Relative abundances of species, based upon light microscope analysis of smear slides is presented in Table 2. Species of nannoconids and other calcareous nannoplankton genera are listed in alphabetical order of species name. This method of data presentation was selected over the procedure of listing species by order of first occurrence because the short time interval recorded in the sediments appears to record few, if any, true biostratigraphic events. First and last occurrences of

'Present address: Texaco, Inc., Los Angeles, California.

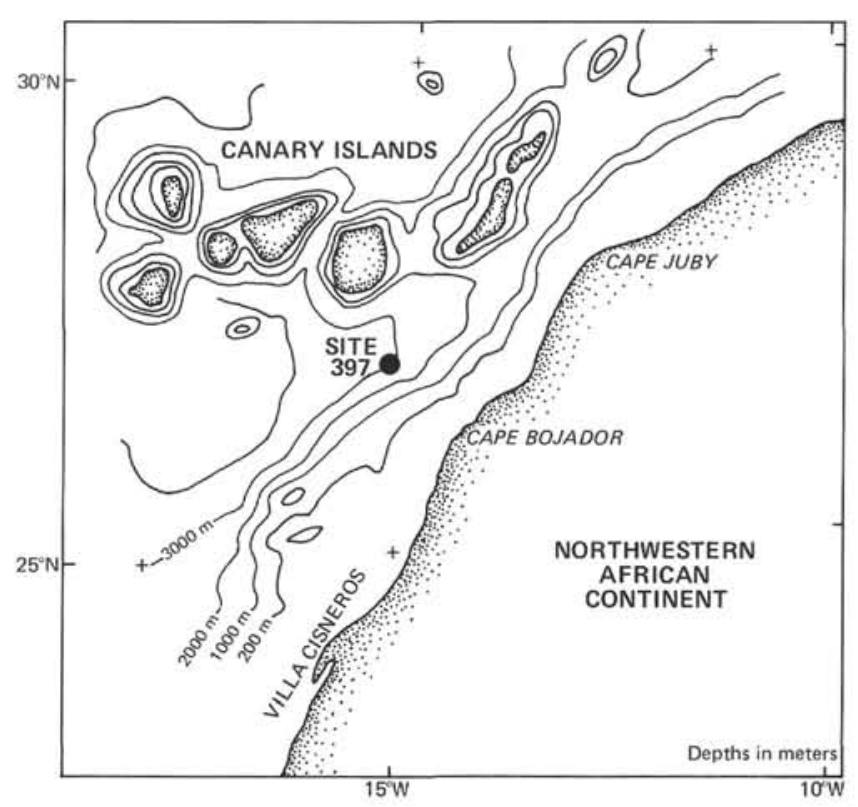

Figure 1. Location of Site 397.

nearly all forms in Hole 397A appear to be largely controlled by preservational effects. The abundance estimation method used is discussed in Čepek (1978). Smear slides were viewed at a magnification of $1560 \times$. Samples with 1 to 10 specimens per field of view are listed as Abundant (A); 1 specimen in 10 fields of view as Common (C); 1 specimen in 50 fields of view as Few (F); 1 specimen in 200 fields of view as Rare (R). The relative abundance of specimens of each species was determined in a similar fashion.

Samples are listed in Table 2 according to core, section, and interval. The quality of preservation for the nannoplankton of each sample is recorded as Good (G), Moderate (M), or Poor (P). This designation represents an average preservation rating for a given sample, as great variance in preservation exists within individual samples. It is not uncommon to observe two specimens of the same species in one field of view; one in a pristine state of preservation, the other heavily dissolved or overgrown.

The presence of siderite, either as individual crystalline grains or as overgrowths on nannoplankton, is also 
TABLE 1

Species Considered in This Report

(listed in alphabetical order of species epithets)

Parhabdolithus asper (Stradner, 1963) Manivit, 1971

Watznaueria barnesae (Black, 1959) Perch-Nielsen, 1968

Watznaueria biporta Bukry, 1969

Discorhabdus sp. aff. D. biradiatus (Worsley, 1971) Thierstein, 1973

Lithraphidites? bollii (Thierstein, 1971) Thierstein, 1973

Watznaueria britannica (Stradner, 1963) Reinhardt, 1964

Nannoconus bucheri Brönnimann, 1955

Lithraphidites carniolensis Deflandre, 1963

Microstaurus chiastius (Worsley, 1971) Grün, 1975

Bipodorhabdus colligatus (Black, 1971) Thierstein, 1976

Nannoconus colomi (deLapparent, 1931) Kamptner, 1938

Watznaueria communis Reinhardt, 1964

Cretarhabdus conicus Bramlette and Martini, 1964

Microstaurus conus (Worsley, 1971) Wind and Čepek, n. comb.

Cretarhabdus crenulatus Bramlette and Martini, 1964

Cruciellipsis cuvillieri (Manivit, 1966) Thierstein, 1971 emend. Wind and Čepek

Axopordorhabdus cylindratus (Noël, 1965) Wind and Wise, 1977

Tetrapodorhabdus decorus (Deflandre, 1954) Wind and Wise, 1977

Cyclagelosphaera deflandrei (Manivit, 1966) Roth 1973

Truncatoscaphus delftensis (Stradner and Adamiker, 1966) Rood, Hay, and Barnard, 1971

Zygodiscus diplogrammus (Deflandre, 1954) Gartner, 1968

Laguncula dorotheae Black, 1971b

Parhabdolithus eboracensis (Black, 1971) Wind and Čepek, n. comb.

Corollithion ellipticum Bukry, 1969

Parhabdolithus embergeri (Noël, 1958) Stradner, 1963

Polypodorhabdus escaigii Noël, 1965

Watznaueria fasciata Wind and Čepek, n. sp.

Reinhardtites fenestratus (Worsley, 1971) Thierstein, 1972

Ethmorhabdus gallicus Noël, 1965

Nannoconus globulus Brönnimann, 1955

Sollasites horticus (Stradner, Adamiker, and Maresch, 1966) Black, 1968

Parhabdolithus infinitus (Worsley, 1971) Thierstein, 1972

Assipetra in fracretacea (Thierstein, 1971) Roth, 1973

Parhabdolithus judithae Black, 1971

Tubodiscus jurapelagicus (Worsley, 1971) Roth, 1973

Nannoconus kamptneri Brönniman, 1955

Stephanolithion laffitteii Noël, 1957

Diazomatolithus lehmani Noël, 1965

Cyclagelosphaera margareli Noël, 1965

Grantarhabdus meddii Black, 1971

Metadoga mercurius Wind and Čepek, n. gen., n. sp.

Conusphaera mexicana Trejo, 1969

Perissocyclus noeliae Black, 1971a emend. Wind and Čepek

Calcicalathina oblongata (Worsley, 1971) Thierstein, 1971

Micrantholithus obtusus Stradner, 1963

Rhabdolekiskus parallelus Wind and Čepek, n. sp.

Manivitella pecten Black, 1971

Manivitella pemmatoidea (Deflandre ex Manivit, 1965) Thierstein, 1971

Lucianorhabdus phlaskus Wind and Čepek, n. sp.

Diloma placinum Wind and Čepek, $\mathrm{n}$. sp.

Octopodorhabdus plethotretus Wind and Čepek, n. sp.

Diloma primitiva (Worsley, 1971) Wind and.Čepek, n. comb.

Diadorhombus rectus Worsley, 1971

Watznaueria reinhardtii Rood, Hay and Barnard, 1971

Discorhabdus rotatorius (Bukry, 1969) Thierstein, 1973

Zeugrhabdotus salillum (Noël, 1965) Rood, Hay and Barnard, 1971

Trapezopentus sarmatus Wind and Čepek, n. gen., n. sp.

Trapezopentus sp. aff, T. sarmatus Wind and Cepek, n. gen., n. sp.

Corollithion senarius Wind and Wise, 1977

Corollithion silvaradion Wind and Wise, 1977

Parhabdolithus splendens (Deflandre, 1953) Noël, 1969

Heleneas taurolithina Worsley, 1971

Vekshinella stradneri Rood, Hay and Barnard, 1971

Cretarhabdus surirellus (Deflandre, 1954) Reinhardt, 1970

Parhabdolithus swinnertonii (Black, 1971) Wind and Čepek, n. comb.

Nannoconus truittii Brönnimann, 1955
TABLE 1 - Continued

Tubodiscus verenae Thierstein, 1973

Nannoconus wassallii Brönnimann, 1955

Biscutum sp.

? Diloma sp.

? Eiffellithus sp.

Lucianorhabdus sp.

Parhabdolithus sp.

Tetrapodorhabdus spp.

recorded. Estimates of the amount of free siderite and carbonate overgrowth on nannoplankton are expressed as Abundant (A), Common (C), Rare (R), or Absent (blank). The values expressed in Table 2 reflect whether all (A), some (C), or few (R) of the specimens are overgrown with secondary carbonate.

Settled slides of the better preserved samples were coated with carbon and/or gold-palladium before being viewed on the light microscope. This procedure resulted in greater ease in identifying forms difficult to resolve in standard light microscope preparations.

Scanning electron micrographs were taken by Mr. E. Knickrem with the Autoscan microscope of the Federal Institute for Geosciences and Natural Resources, Hannover, Germany (BGR), and by William I. Miller, III, with a Cambridge S4-10 microscope of the Department of Biological Science, Florida State University, Tallahassee, Florida. Primary support for Čepek was provided by the Deutsche Forschungsgemeinschaft and BGR. We thank Hans R. Thierstein (Scripps Institution of Oceanography, La Jolla) for suggestions concerning the systematics and biostratigraphic determinations, and David Bukry (U.S. Geological Survey, La Jolla) and Peter H. Roth (Univ. of Utah, Salt Lake City) for reviewing an early draft of the manuscript.

\section{CALCAREOUS NANNOPLANKTON BIOSTRATIGRAPHIC ZONATIONS AND DATUMS}

Biostratigraphic zonation of the Lower Cretaceous used in this study is from Thierstein $(1971,1973)$; Roth (1973); and Sissingh (1977). The zones recognized by these authors, and defining biostratigraphic datums for the upper Valanginian through lower Barremian are presented in Figure 2. Key species for mid-Early Cretaceous age determinations include Nannoconus colomii, N. bucheri, Cruciellipsis cuvillieri, Bipodorhabdus colligatus, Calcicalathina oblongata, Lithraphidites? bollii, Tubodiscus verenae, and T. jurapelagicus. The stratigraphic position of datums proposed by Thierstein (1976) and Roth (1973) is shown in Figure 3.

Roth (1973, p. 697) proposes the Tubodiscus jurapelagicus Zone be defined by the first and last occurrences of this species. Unfortunately, the generally poor preservation of the section for which this zone was proposed, and the sporadic occurrence of recognized Early Cretaceous markers prevents an accurate dating of the last occurrence of this taxon within the Hauterivian. This species occurs sporadically throughout Hole 397A.

Although we question the generic placement of Lithraphidites bollii and acknowledge that its morphology 
TABLE 2

Distribution of Calcareous Nannoplankton Species in the Hauterivian Sediments of Hole 397A

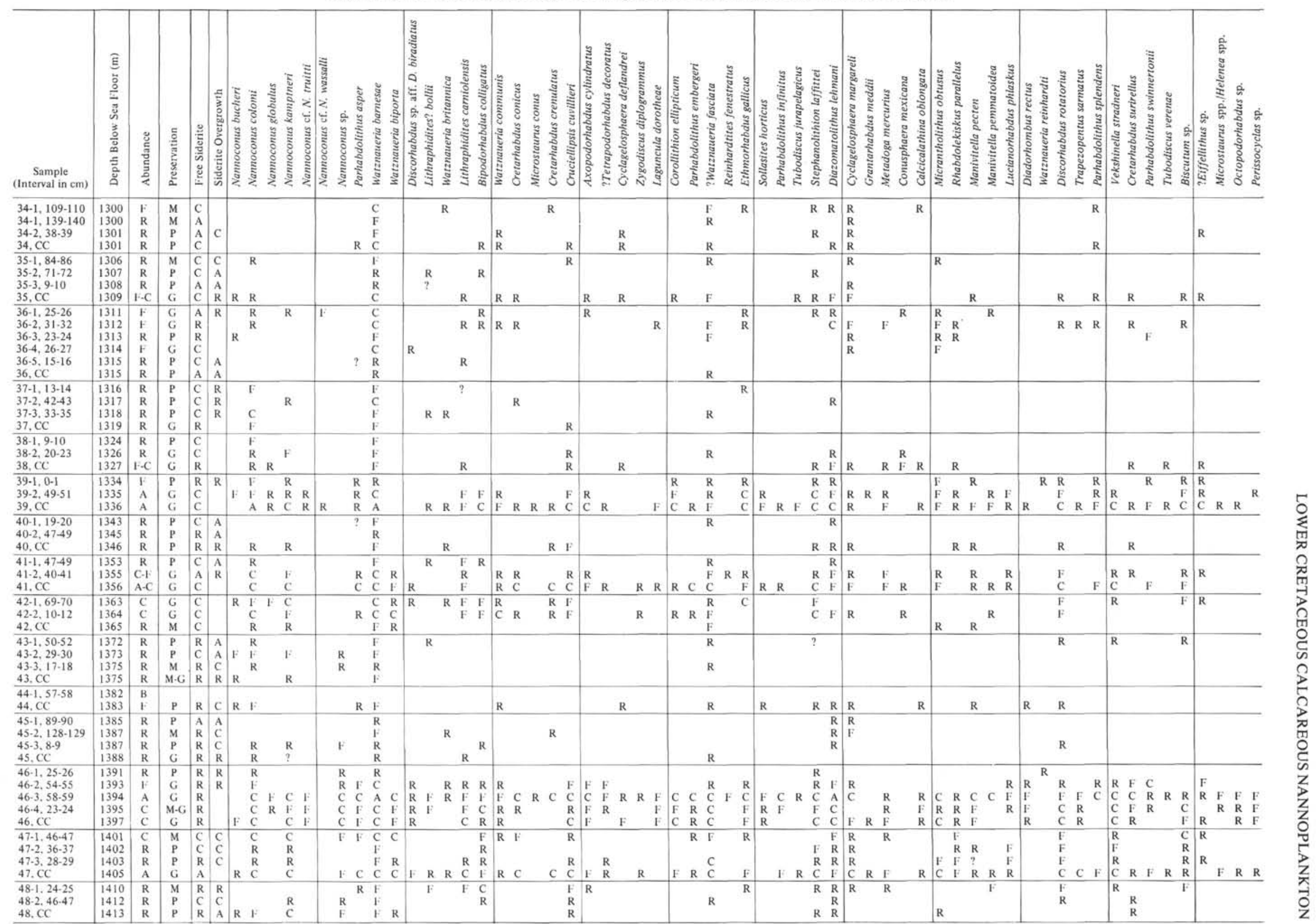


TABLE 2 - Continued

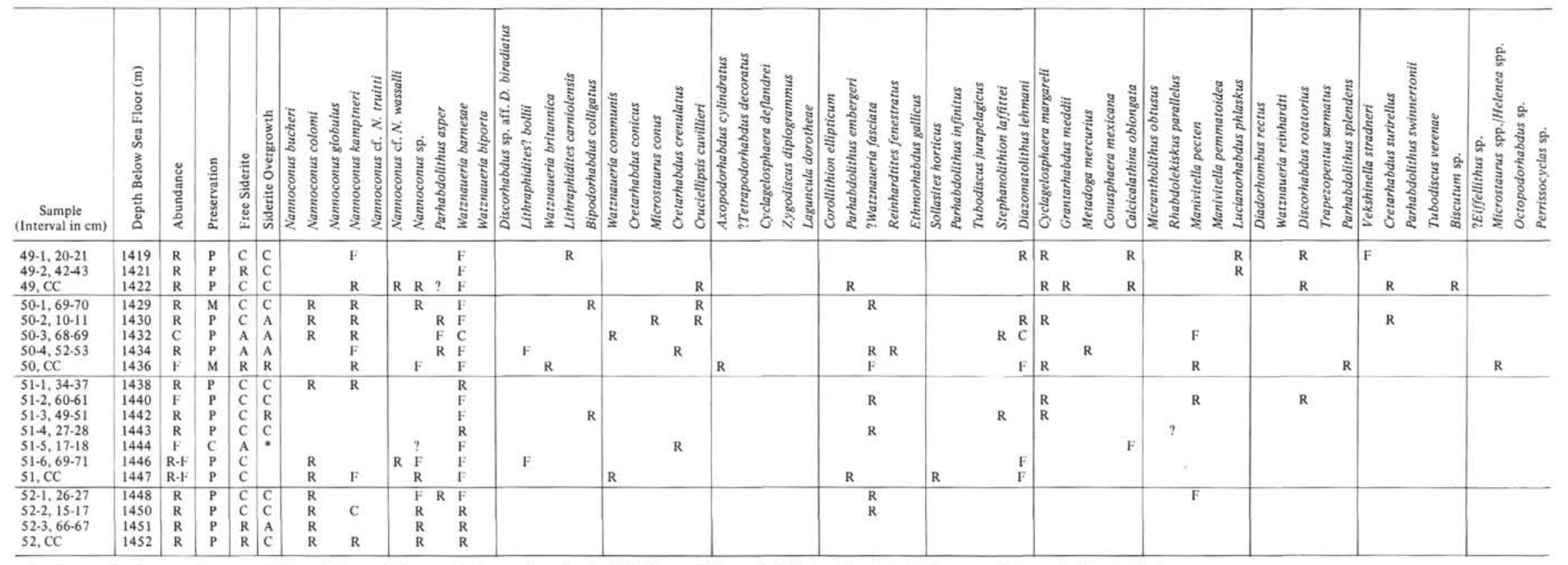

Abundance: Abundant $=$ A, Common $=$ C, Few $=$ F, Rare $=$ R, Barren $=$ B. Preservation: Good $=$ G, Moderate $=$ M, Poor $=$ P. Siderite: Abundant $=A$, Common $=C$, Rare $=$ R, Absent $=$ blank.

Note: Assipetra infracretacea (Thierstein) Roth may be present in many of the samples, but was not recorded due to the possibility of confusing it with siderite crystal aggregates. An asterisk in the column recording siderite overgrowth indicates that calcite, rather than siderite overgrowth, is present. 


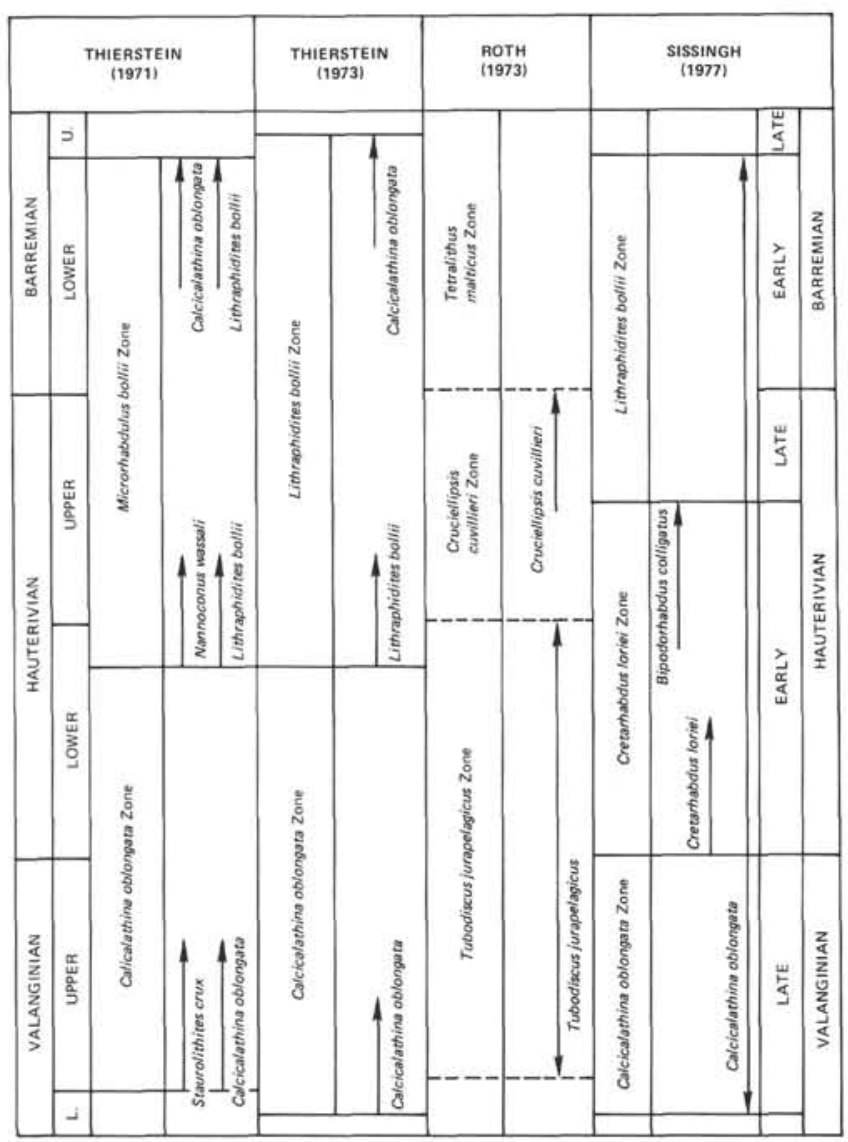

Figure 2. Biostratigraphic zones and defining datums for the upper Valanginian through lower Barremian proposed by Thierstein (1971, 1973); Roth (1973); and Sissingh (1977).

and stratigraphic range are probably affected by preservational conditions, this species when present may serve as a useful biostratigraphic marker in the Hauterivian and Barremian. The most complete record of the range of $L$. ? bollii is described by Thierstein (1973, fig. 10) from the Hauterivian section at La Charce, and from the type section of the Barremian near Angles (Thierstein, 1973, fig. 11). The first occurrence of $L$. ? bollii is at the base of the upper third of the lower Hauterivian (Sample Th 70/134) in the La Charce section. This species is not recorded from lower samples with apparently equally diverse and well-preserved nannofloras (Samples Th 70/131a, 129a, 127a). It appears likely that the first occurrence of L.? bollii in the La Charce section is a valid biostratigraphic event, and the presence of this form may be useful for distinguishing between the lower and upper portions of the Hauterivian.

Thierstein (1976, fig. 7) indicates the known ranges of several additional Early Cretaceous species which are of use in determining the age of the Hole 397A section. However, several of these ranges as presented in Thierstein (1976)are in need of emendation. They include:

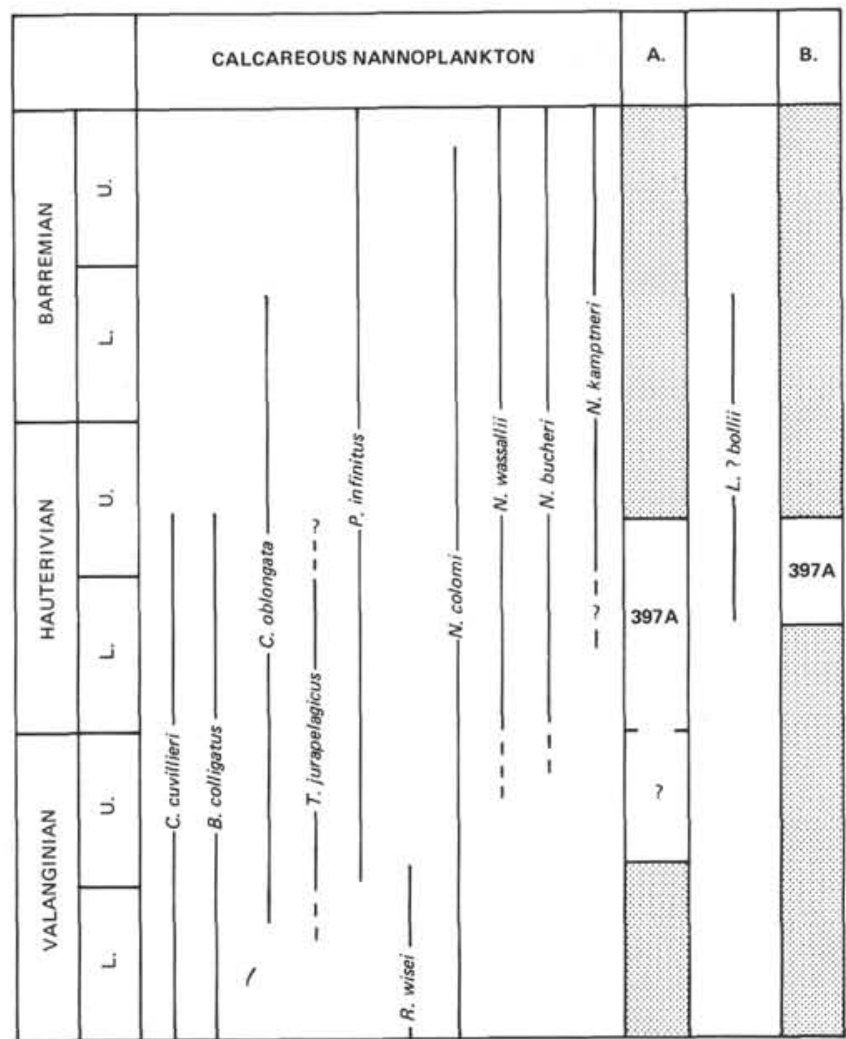

Figure 3. Ranges of key Valanginian through Barremian calcareous nannoplankton and age assignment of the Lower Cretaceous section from Hole 397A. Ranges given are from Thierstein $(1971,1973,1976)$ and Roth (1973). (A) Age limits of the Hole 397A section using only well-documented, dissolution-resistant species. (B) Age limits of the Hole 397 A section if the first occurrence datum of Lithraphidites? bollii is recognized as a valid biostratigraphic datum.

Cyclagelosphaera deflandrei (Manivit) Roth, 1973

Highest occurrence: Top of Valanginian.

Remarks: Roth $(1973,697)$ notes that this species diappears close to the top of the Cruciellipsis cuvillieri Zone. The range of this species, which occurs rarely throughout the Hole 397A section, is extended to the late Hauterivian.

Diadorhombus rectus Worsley, 1971

Highest occurrence: Mid-late Valanginian.

Remarks: Although Thierstein $(1971,1973,1976)$ indicates that Diadorhombus rectus is restricted to the Valanginian, it may be possible to argue that this species persisted into the Hauterivian. Unfortunately, the precise age of the biostratigraphic datum upon which this extension is based, i.e., the first occurrence of Lithraphidites? bollii, is not well documented. Worsley (1971, p. 1309; table 2) reports the occurrence of Diadorhombus rectus in three samples, one of which, Sample E (5A-4-1, $30 \mathrm{~cm})$, he dated as Hauterivian. The 
presence of $D$. rectus in this sample has been confirmed by F. H. W. in the present study. Thierstein (1973, fig. 17) placed a sample taken $5 \mathrm{~cm}$ below Worsley's Sample $E$ in the late Hauterivian, apparently based largely upon the presence of Lithraphidites bollii. Thierstein (1971, fig. 5) also found both $L$. bollii and Diadorhombus rectus in Sample 4-4-1, $11 \mathrm{~cm}$ (mislabeled as 4-4-1, $25 \mathrm{~cm})$.

The age of the highest occurrence of Diadorhombus rectus therefore depends upon the age of the first occurrence of Lithraphidites? bollii. L.? bollii appears to be more resistant to dissolution than Diadorhombus rectus and is probably a more reliable marker species in sections with less-than-ideal nannoplankton preservation. In Worsley's Sample E, Diadorhombus rectus is accompanied by large numbers of Corollithion ellipticum. Diadorhombus and Corollithion appear to share the same susceptibility to dissolution, and it is expected that samples from within the range of Diadorhombus rectus would contain neither or both forms. Neither species is recorded from the reference sections in southeastern France studied by Thierstein. Assuming that the first occurrence of Lithraphidites? bollii is a "mid" Hauterivian event, the range of Diadorhombus rectus is extended to at least that level in the Early Cretaceous.

Diadorhombus rectus is present in many wellpreserved samples from Hole 397A. The highest sample in which it was found during the preparation of Table 2 is $397 \mathrm{~A}-44, \mathrm{CC}$. A single specimen was observed in Sample 397A-39, CC.

\section{Tubodiscus verenae Thierstein, 1973}

Highest occurrence: Mid-late Valanginian.

Remarks: Although Thierstein (1973, p. 43) restricts $T$. verenae to the Valanginian, he indicates (1973, fig. 17) that this form may extend as high as late Hauterivian (higher occurrences are interpreted by him as the result of reworking). Wise and Wind (1977) indicate that forms having an affinity to Tubodiscus verenae may have persisted to at least the Albian. We do not recognize the expanded definition of $T$. verenae as proposed in Grun and Allemann (1975), which would place the last occurrence of Tubodiscus verenae in the Maestrichtian. Rare specimens of this species occur throughout the section from Hole 397A.

Sissingh (1977) proposes several zones for the Early Cretaceous utilizing biostratigraphic datums other than those recognized by Thierstein. These datums include:

\section{Cretarhabdus loriei Gartner, 1968}

Lowest occurrence: Early Hauterivian.

Remarks: Thierstein (1973) indicates that the lowest known occurrence of this species is late Aptian. C. loriei was not observed in any Hole 397A samples.

\section{Paleopontosphaera salebrosa (Black) Prins and Sissingh, 1977}

Highest occurrence: Mid-early Hauterivian.

Remarks: Cruciplacolithus salebrosa Black (1971, pl. 30 , fig. 4) is a $5.6 \mu \mathrm{m}$ diameter placolith with a cruci- form central structure illustrated in proximal view with a transmission electron micrograph. Although similar in size to specimens recorded in Table 2 as Biscutum sp., forms exhibiting the behavior in cross-polarized light of Paleopontosphaera salebrosa as described in Sissingh (1977) were not observed.

\section{AGE OF THE LOWER CRETACEOUS SEDIMENTS FROM HOLE 397A}

Two ranges in age for the Early Cretaceous at Hole 397A are presented in Figure 3. The first approach (Figure $3 \mathrm{~A}$ ) relies upon several key species which are preserved in most geologic sections and whose biostratigraphic datums are well documented. The persistent presence of Cruciellipsis cuvillieri and Bipodorhabdus colligatus indicate that the entire section is older than uppermost Hauterivian. The presence of Calcicalathina oblongata and Parhabdolithus infinitus, and the absence of Rucinolithus wisei indicate a post-early Valanginian age. Rucinolithus wisei is present in Berriasian and Valanginian samples from Site 367 (Cepek, 1978, table 6). The nannoconid assemblage, with Nannoconus bucheri, $N$. kamptneri, and $N$. cf. $N$. wassallii, suggests that the entire section is Hauterivian.

The emendation of the ranges of Diadorhombus rectus, Tubodiscus verenae, and Cyclagelosphaera deflandrei eliminates any solid evidence for a pre-Hauterivian age. Using the species discussed above, the Lower Cretaceous section recovered at Hole 397A is dated as postearly Valanginian and pre-latest Hauterivian. The section would be placed in the Calcicalathina oblongata Zone or lower part of the Lithraphidites bollii Zone of Thierstein $(1971,1973)$, in the Tubodiscus jurapelagicus Zone of Roth (1973), and in the Calcicalathina oblongata Zone or Cretarhabdus loriei Zone of Sissingh (1977).

If we view the first occurrence of Lithraphidites? bollii as a valid biostratigraphic event in the uppermost early Hauterivian, then the section at Hole 397A could only range from uppermost early Hauterivian to the mid-late Hauterivian (see Figure 3B). The two datums defining this interval are the first occurrence of Lithraphidites? bollii and the last occurrence of Bipodorhabdus colligatus. If this is the correct age determination for the sediments at Hole 397A, the 153 meters of recovered section may only record sedimentation off Cape Bojador during a period as short as two million years.

\section{NANNOFLORAL COMPOSITION, PRESERVATION, AND ENVIRONMENT OF DEPOSITION}

Key references for the identification of nannoplankton from Hole 397A include Black (1971, 1972, 1973, 1975); Worsley (1971); and Thierstein (1971, 1973, 1976). Grun and Allemann (1975) describe a fairly diverse nannoflora from the Berriasian of Spain containing many species observed in Hole 397A samples. Unfortunately, their samples have been subjected to extensive carbonate overgrowth, and the absence of several genera known to have existed during the Berriasian indicates that a portion of the nannoflora has been 
removed by dissolution. Several samples from DSDP Leg 1 (Holes 4 and 5A) in the Blake-Bahama Basin contain calcareous nannofloras which closely approach those of Hole 397A both in diversity and overall population composition. These samples have been studied by Bukry and Bramlette (1969), Worsley (1971), and Thierstein $(1971,1973)$.

Sediment from Hole 397A is an admixture of detrital, chemical, and biogenic components: detrital silts and clay, siderite, and calcareous nannoplankton. Few other fossil remains are present, with the exception of occasional ammonite fragments and rare foraminifers. Most of the samples contain only rare nannoplankton. These samples are typified by generally poor preservation and rare to common free siderite (individual crystal grains). Most or all specimens in these samples are modified by carbonate overgrowth.

Samples with common to abundant nannoplankton are, in comparison, characterized by good preservation and little or no overgrowth. Free siderite ranges from rare to common. Several samples, most commonly in Cores $39,41,42$, and 47 , contain both well-preserved nannoplankton and common to abundant free siderite.

It is not uncommon to observe specimens of the same species in a single sample in various states of preservation. Specimens of Watznaueria and Cyclagelosphaera in some samples may be extensively overgrown while other species, or other specimens of Watznaueria and Cyclagelosphaera in the same field of view, may be totally unaltered. In some samples, specimens of Stephanolithion laffittei are present in every conceivable fashion of preservation.

The material which has overgrown many of the calcareous nannoplankton in Hole 397A appears to be siderite, rather than calcite. Siderite overgrowth of nannoplankton has heretofore not been described (Roth, 1978, personal communication). Heavily encrusted specimens are bright yellow-orange in transmitted light. This color is indistinguishable from that of free siderite grains in the sediment. While calcite can appear yellow if sufficiently thick, this same intense color is characteristic of small overgrown placoliths and rhabdoliths. Only one sample (397A-51-5, 17-18 cm) contains a nannoflora modified by what appears to be calcite overgrowth.

Several forms of nannoplankton have the potential to serve as monitors of carbonate dissolution and reprecipitation. Metadoga mercurius, n. gen., n. sp., and Lucianorhabdus phlaskus, n. sp., are holococcoliths, forms constructed of $0.1 \mu \mathrm{m}$ calcite rhombs. As discussed in Wind and Wise (1978), Upper Cretaceous holococcoliths of the genus Lucianorhabdus are highly susceptible to pre- or syn-depositional dissolution. However, once incorporated into the sediment, they may become active centers for carbonate overgrowth. At least nine samples from Hole 397A contain specimens of Metadoga or Lucianorhabdus. These samples contain common siderite in the form of free crystals and/or overgrowth on nannoplankton. No specimens of holococcoliths in these or other samples show any evidence of overgrowth when viewed on the light micro- scope. The wholesale migration of carbonate needed to overgrow heterococcoliths in these samples, and form the large siderite crystals observed, would surely have altered the appearance of the holococcoliths.

Several depositional models may be invoked to explain the mode of heterogeneous preservation observed in the Hole 397A samples. The samples from Hole 397A may consist of sediments reworked from shallower waters. Siderite-bearing sediment may have been mixed with well-preserved siderite-poor sediments, or the well-preserved nannoplankton may represent the only autochthonous sediment component deposited at the site. An alternate explanation is that geochemical activity relating to the formation of siderite and the dissolution and overgrowth of calcareous nannoplankton is confined to extremely narrow zones around siderite-crystallization centers or is restricted to thin laminae. Smear slides would incorporate material from several of these laminae and from areas of sideritegrowth activity and chemically stable regions.

\section{SUMMARY AND CONCLUSIONS}

1. Drilling at DSDP Hole 397A in the eastern Atlantic Ocean recovered 153 meters of Hauterivian sideritic mudstones. These Cretaceous sediments are overlain by a thick Neogene section, with the unconformity placed at approximately 1300 meters subbottom depth.

2. Nannofloras from this site are often well preserved and far more diverse than any reported to date, consisting of well-documented Lower Cretaceous species, new taxa, delicate forms previously described only from the Albian of England, and forms more commonly associated with Upper Jurassic nannofloras. It now appears that the ranges of many taxa in the Early Cretaceous are influenced more by preservational effects than by the true stratigraphic range of the species.

3. While a zonation utilizing only dissolutionresistant nannoplankton indicates a possible range in age from late Valanginian to late Hauterivian, the recognition of the first occurrence datum of Lithraphidites? bolli places the Hole 397A section in the interval from uppermost early Hauterivian through the early late Hauterivian.

4. The presence of Metadoga mercurius, n. gen., n. sp., and Lucianorhabdus phlaskus, n. sp., extend the range of holococcoliths to the Hauterivian.

5. The enigmatic co-existence of well-preserved and poorly preserved specimens in single samples, and the occurrence of siderite crystals in samples with totally unmodified specimens of highly overgrowth-susceptible taxa suggest that much of the section recovered at Hole 397A consists of allochthonous sediments incorporating both well-preserved and poorly preserved biogenic material. An alternate hypothesis is that the sediments from Hole 397A consist of allochthonous siderite-rich siltstones which have incorporated a well-preserved autochthonous component. In either case, the quality of preservation of the nannoplankton suggests rapid sedimentation in fairly shallow water. 


\section{SYSTEMATIC PALEONTOLOGY}

Repository for type specimens is the U.S. National Museum (USNM), Washington, D.C.

Genus AXOPODORHABDUS Wind and Wise, 1977

Axopodorhabdus cylindratus (Noël, 1965) Wind and Wise, 1977

(Plate 4, Figures 13, 14)

Podorhabdus cylindratus Noel, 1965, p. 103-104, fig. 30, pl. 9, fig. $3,7$.

Axopodorhabdus cylindratus (Noël) Wind and Wise in Wise and Wind, 1977 , p. 297 , pl. 80 , fig. 5, 6 ; pl. 81 ; fig. $1-4$, pl. 88 , fig. 5, 6 . Podorhabdus septentrionalis Black, 1971, p. 407-408, pl. 32, fig. 5.

Remarks: Specimens of Axopodorhabdus from Hole 397A are placed in $A$. cylindratus (Noël) rather than in $A$. dietzmannil (Reinhardt) Wind and Wise because of the equal width of the four bars supporting the stem. A. dietzmannii has a more elongate base, accompanied by a broadening of the short axis crossbars. Specimens from Hole 397A are nearly indistinguishable from Upper. Jurassic forms illustrated in Noèl (1965, 1973 [1972]) and Wise and Wind (1977). Podorhabdus septentrionalis Black is similarly constructed and was reported from the Berriasian and Hauterivian.

This species is fairly common in well-preserved samples from Hole $397 \mathrm{~A}$, but because of the lack of secondary mineralization, is difficult to identify. Specimens are more visible if slides are first coated with carbon and/or gold-palladium.

\section{Genus CRUCIELLIPSIS Thierstein, 1971 emend. Wind and Čepek}

Description: Broad rim of imbricate elements surrounding a small central area spanned by four radial bars aligned with the long and short axes of the ellipse. A fibrous stem arising from the junction of the crossbars may be present. Narrow bars may pave the proximal surface of the coccolith between the crossbars and rim.

Remarks: This genus is distinguished from Cretarhabdus Bramlette and Martini by its wider rim and smaller central area. In Cretarhabdus, central area structures in addition to the four axial bars are more nearly the same size as the axial bars and are affixed to the distal portion of the shield. In Cruciellipsis, accessory structures, if present, lie on the proximal surface of the specimen, and might be interpreted as ornamental.

Cruciellipsis is distinguished from Helenea Worsley, 1971, and Microstaurus Black, 1971, by the presence of a more fibrous crossbar and stem complex, and by greater ellipticity. Five laths paving the area between crossbars and rim of specimens of $C$. cuvillieri have not been observed on specimens of Helenea and Microstaurus from Hole 397A.

Cruciellipsis cuvillieri (Manivit, 1966) Thierstein, 1971, emend. Wind and Čepek

(Plate 2, Figures 11-13)

Coccolithus cuvillieri Manivit, 1966, p. 268, fig. 2a, b, c, 3a, b.

?Cruciellipsis sp. - Bukry and Bramlette, 1969, pl. 3, fig. c, d; pl. 5, fig. c.

Coccolithus cuvillieri Manivit - Worsley, 1971, p. 1309, pl. 2, fig. 34-36.

Crucillipsis cuvillieri (Manivit, 1966) Thierstein, 1971, p. 478, pl. 5, fig. 4-8.

Cruciellipsis cuvillieri (Manivit) Thierstein, 1971 - Grun and Allemann, 1975, p. 179-180, text-fig. 21, pl. 4, fig. 9-12.

Description: Broad rim of elements surrounding small central area. Central area spanned by four radial bars often terminating in a central stem. Approximately five narrow parallel crystals extend from the axial crossbars to the rim.

Remarks: This emendation is based upon features not evident in less well-preserved specimens. Forms from Hole 397A are indistinguishable on the light microscope from specimens previously illustrated.

Hypotype: USNM 245042 (Plate 2, Figure 13).

Occurrence: Uppermost Tithonian-upper Hauterivian.

Genus DILOMA Wind and Čepek, n. gen.

Type species: Diloma primitiva (Worsley, 1971) Wind and Čepek, n. comb.

Description: Complex rim of short radial elements surrounds an area paved with thin parallel laths which extend from the rim to a thin crossbar on the long axis of the ellipse. A curved bar crosses all radial elements and is located parallel to, and just inside of, the rim. Specimens with a central stem supported by axial supports have the thin parallel laths restricted to the outer portion of the central area.

Remarks: The genus name is from the Greek $d i=$ two; loma $=$ fringe, border. The nature of the construction of the rim is not known in detail, as most observations are by light microscope.

The appearance of this genus in phase contrast and cross-polarized light suggests that these forms are not related to the podorhabdids or cretarhabdids.

Diloma primitiva (Worsley, 1971) Wind and Čepek, n. comb. (Plate 8, Figures 2, 3)

Arkhangelskiella primitiva Worsley, 1971, p. 1306, pl. 1, fig. 1-3.

Description: Complex elliptical form with narrow central stem supported by thin bars aligned with the axes of the ellipse. A thincurved strut parallels the rim, dividing the central area into two concentric sections. Thin bars extend inward from the rim to this elliptical inner support.

Remarks: The specimen illustrated in Plate 8 appears to be identical to that illustrated in Worsley, 1971. As discussed above, the appearance of the rim on the light microscope suggests that this form has no affinity to any presently recognized taxa.

Occurrence: Hauterivian of DSDP Hole 397A. Worsley's specimen is from Sample $5 A-4-1,30 \mathrm{~cm}$. Thierstein (1973) subsequently dated this sample as Hauterivian.

\section{Diloma placinum Wind and Čepek, n. sp.}

(Plate 8, Figures 1, 4-7)

Description: Elliptical form with complex rim and central area filled with thin parallel bars which extend from another thin bar along the long axis to the rim. A curved bar which connects all of these thin bars is situated just inside of the rim.

Remarks: The species name is from the Greek plakos $=$ made of boards. This form is difficult to resolve on the light microscope; however, the general appearance of the rim, especially in crosspolarized light, suggests an affinity with Diloma primitiva (Worsley, 1971) Wind and Cepek. It differs from the latter species in the presence of more numerous, thinner parallel bars, and the absence of a stem. The central area of Diloma sp. is bright in cross-polarized light, while the central area of $D$. placinum remains generally dark. 397A

Occurrence: Known only from the Hauterivian of DSDP Hole

Size: Maximum length 7.8 to $9.0 \mu \mathrm{m}$; holotype $8.6 \mu \mathrm{m}$.

Holotype: USNM 256051 (Plate 8, Figure 1).

Isotypes: USNM 256052, 256053.

Type Locality: Eastern Atlantic Ocean, Sample 397A-46-3, 58-59 cm (1394 m).

\section{Diloma sp.}

(Plate 8, Figures 8-17)

Description: Elliptical placolith with central area bright in crosspolarized light. The central area is either divided into four quadrants whose boundaries are coincident with the ellipse axes, or into six sections, two of which are small triangular segments which are situated along the short axis. Diagonally opposed quadrants have similar properties in cross-polarized light.

Remarks: The proposing of a formal species name for this group awaits more detailed electron microscope analysis. These forms appear to bear a secondary inner support adjacent to the rim as is present in Diloma placenum Wind and Čepek, $\mathrm{n}$. sp. The specimens illustrated in Plate 8, Figures 8-17, may represent overgrown specimens of this latter species.

Size: Maximum length 7.5 to $9.0 \mu \mathrm{m}$.

Occurrence: Hauterivian of DSDP Hole 397A.

\section{Genus DISCORHABDUS Noël, 1965}

Discorhabdus sp. aff. D. biradiatus (Worsley, 1971) Thierstein, 1973 (Plate 5, Figures 6-10)

?Rucinolithus biradiatus Worsley, 1971, p. 1311, pl. 1, fig. 51, 52.

?Discorhabdus biradiatus (Worsley) Thierstein, 1973, p. 42, pl. 6, fig. 7-11. 
Description: Small rhabdolith constructed of long narrow stem and two shields of radically different construction. The long cylindrical stem is slightly tapered just before it flares at the end. The distal shield is constructed of approximately 13 irregular petaloid overlapping elements.

Remarks: Details of the proximal shield are not known. With the exception of the greater number of distal shield elements (13 vs. 8-11 in Discorhabdus biradiatus) and the fact that the distal shield is curved, forms observed in Hole 397A samples greatly resemble the previous-named species. The base of this form is readily distinguishable from that of Discorhabdus rotatorius (Bukry) Thierstein, 1973, especially in cross-polarized light.

Size: Width of distal shield 3.2 to $4.1 \mu \mathrm{m}$; height of stem 4.1 to $4.8 \mu \mathrm{m}$.

Genus EIFFELLITHUS Reinhardt, 1965, emend. Reinhardt, 1966 ? Fiffellithus sp.

(Plate 10, Figures 5-13)

Description: Small elliptical forms with a narrow rim and small structure in the center in the shape of an "X."

Remarks: With the exception of their small size and absence of a well-developed spine, these specimens greatly resemble Eiffellithus turriseiffeli (Deflandre and Fert) Reinhardt. Specimens of $E$. turriseiffeli are generally between 7.0 and $10 \mu \mathrm{m}$ in greatest dimension, while the forms from Hole $397 \mathrm{~A}$ are between 2.5 and $3.0 \mu \mathrm{m}$. The oldest recorded occurrence of a species of Eiffellithus is from the middle Albian. E. turriseiffeli has a first occurrence in the late Albian (Thierstein, 1973, 1976).

\section{Genus ETHMORHABDUS Noel, 1965 \\ Ethmorhabdus gallicus Noel, 1965}

(Plate 6, Figures 7-12)

Ethmorhabdus gallicus Noël - Noēl, 1965, p. 110-112, fig. 33, 34, pl. 10, fig. 1, 2, 5 .

Cribrosphaera hauterivia Black, 1971a, p. 421, pl. 33, fig. 8 .

Remarks: This species, with the exception of the single specimen illustrated by Black (1971a), has not been illustrated from postJurassic sediments. Worsley (1971, Table 2) indicates the presence of Ethmorhabdus gallicus in samples from DSDP Sites 4 and 5 which were subsequently dated as Valanginian and Hauterivian by Thierstein (1971, 1973).

This species is fairly common in well-preserved samples. Its absence in many previously studied Lower Cretaceous samples is attributed to dissolution effects.

Occurrence: Bajocian to Hauterivian.

\section{Genus LAGUNCULA Black, 1971}

Laguncula dorotheae Black, 1971b

(Plate 11, Figures 17-19)

Laguncula dorotheae Black, 1971b, p. 327, pl. 2, fig. a.

Laguncula dorotheae Black - Wise and Wind, 1977, p. 300, pl. 73, fig. 3-7.

Description: Hollow globular body arising from a narrow cylindrical neck. The walls of the globe produce a cancellate pattern in both phase contrast and cross-polarized light.

Remarks: Several of the specimens of this species from Hole 397A appear to possess a small tabular base. The general appearance of the inflated portion of specimens of this species, and the possible presence of a basal plate suggests that Laguncula dorotheae may be related to the parhabdolithids with similarly inflated spines (Parhabdolithus swinnertoni [Black], P. judithae Black, and ?Parhabdolithus of this report).

Occurrence: Previously reported only from the Albian.

Laguncula sp. aff. L. dorotheae Black, 1971b

(Plate 11, Figures 20, 21)

Remarks: Several specimens of Laguncula from Hole 397A appear to possess a greater thickening of the wall of the inflated region. It is not known whether this feature is a valid distinguishing feature, or the result of calcite overgrowth.
Genus LITHRAPHIDITES Deflandre, 1963

\section{Lithraphidites? bollii (Thierstein, 1971) Thierstein, 1973}

(Plate 3, Figures 12-17)

Microrhabdulus bollii Thierstein, 1971, p. 481, pl. 3, fig. 6-10. Lithraphidites bollii (Thierstein, 1971) Thierstein, 1973. p. 45.

Lithraphidites bollii (Thierstein, 1971) Thierstein 1973 - Thierstein, 1976 , p. 350 , pl. 3, fig. $24-26$.

Description: Long rhabdolith with small tabular base and blocky stem.

Remarks: Forms clearly identifiable as Lithraphidites bollii as illustrated in Thierstein $(1971,1976)$ were not observed in Hole 397A. However, many samples contain blocky-stemmed rhabdoliths which if subjected to dissolution of the base and crystalline overgrowth of the stem, would approach the appearance of $L$. bollii. Thierstein (1978, personal communication) notes that although the transition in morphology from that exhibited in Hole 397A to that present in the poorly preserved samples from France and Switzerland can only be demonstrated through high-pressure and high-temperature bomb experiments, the specimens from Hole 397A appear to represent the original less altered morphology of Lithraphidites? bollii.

Occurrence: Lithraphidites bollii (Thierstein) is known to range from early Hauterivian to early Barremian.

Size: Length of stem 7.0 to $20.0 \mu \mathrm{m}$; width of base 3.0 to $5.0 \mu \mathrm{m}$.

\section{Genus LUCIANORHABDUS Deflandre, 1959 \\ Lucianorhabdus phlaskus Wind and Čepek, n. sp. (Plate 9, Figures 1-3, 7-10)}

Description: Elongate holococcolith with small tabular base and narrow cylindrical neck terminating in a large spherical tip. The base is approximately twice as wide as high. The height of the cylindrical neck and height and width of the bulbous terminus are variable. Diameter of the bulb is usually wider than the base.

Remarks: The species name is from the Greek phlaske $=$ wine flask. This species, along with Metadoga mercurius Wind and Čepek, n. gen., n. sp., and a variety of small rhabdoliths and elliptical plates having affinity with Campanian and Maestrichtian holococcoliths, is the oldest known representative of this morphological group. Their presence in the Hole 397A section is the only known Early Cretaceous occurrence of holococcoliths.

Lucianorhabdus phlaskus is distinguished from other lucianorhabdid holococcoliths by the presence of a bulbous stem, and from Metadoga mercurius by the bulbous stem and well-developed basal plate.

Occurrence: This species is known only from the Hauterivian of Hole 397A.

Size: Length 5.0 to $6.2 \mu \mathrm{m}$; holotype $5.6 \mu \mathrm{m}$. Width of bulb 2.2 to $3.4 \mu \mathrm{m}$; holotype $2.6 \mu \mathrm{m}$.

Holotype: USNM 256054 (Plate 9, Figures 1-3).

Isotypes: USNM 256055, 256056.

Type locality: Eastern Atlantic Ocean, Sample 397A-46-3, 58-59 $\mathrm{cm}(1394 \mathrm{~m})$.

\section{Lucianorhabdus sp.}

\section{(Plate 9, Figures 14-18)}

Remarks: Several small lucianorhabdids were observed in samples from Hole 397A. They are somewhat variable in form, with greatest differences in the length of the stem. The presence of a cap or lid in the most common form (illustrated in Plate 9, Figures 14,15) suggests an affinity with Lucianorhabdus compactus (Verbeek) Prins and Sissingh, 1977 (compare with Verbeek, 1976, pl. 2, fig. 3a, 3b). The variation in stem length is a feature common in Upper Cretaceous holococcolith assemblages. Small elliptical plates with central pores common in several well-preserved samples resemble several forms described from the Maestrichtian and Campanian by Čepek (1970), Risatti (1972), and Wise and Wind (1977).

Genus METADOGA Wind and Čepek, n. gen.

Type species: Metadoga mercurius Wind and Čepek, n. sp.

Description: Hollow, conical holococcolith with cylindrical neck. Main chamber conical to trapezoidal in cross-section. Neck may be 
cylindrical for entire length or flare slightly at terminus. Top of neck closed by a plate set within the rim of the neck. A crystalline collar may ring specimens at the point of juncture of the main body and neck.

Remarks: Genus name is from the Latin meta = conical figure, $\operatorname{dog} a=\mathrm{a}$ vessel. This genus is distinguished from Lucianorhabdus by the absence of a basal plate. The absence of recognizable basal structure prevents identification of proximal and distal portions.

\section{Metadoga mercurius Wind and Čepek, n. sp.} (Plate 9, Figures 4-6, 11-13, 19, 20)

Description: Tapered conical chamber terminating in a cylindrical neck. A small plate may be set within the aperture of the short neck. A short crystalline collar may circle the region of juncture of cylindrical collar and main body.

Remarks: The species name is from the Latin mercurius = messenger of the gods. This form is distinguished from Lucianorhabdus phlaskus Wind and Cepek, n. sp., by its conical to trapezoidal shape, possible presence of a collar, and the absence of a clearly defined base. Differences between the many specimens observed on the light microscope are viewed as the result of differences in orientation, and as a result, the genus Metadoga is presently considered to be monospecific. It is now known whether the presence or absence of a collar, as is present on the holotype, is a valid criterion for proposing an additional species.

These forms are occasionally found in clusters (see Plate 9, Figures 11-13), suggesting that the secreting organism bore at least several of these skeletal elements at one time.

Along with species of Lucianorhabdus, Metadoga mercurius is among the oldest known holococcoliths. The previous oldest reported occurrence of a holococcolith is Lucianorhabdus compactus (Verbeek) Prins and Sissingh (= Isocrystallithus compactus Verbeek) from the Cenomanian.

Occurrence: Metadoga mercurius has only been observed in the Hauterivian sediments from Hole 397A.

Size: 4.5 to $6.0 \mu \mathrm{m}$ height, 5.0 to $7.0 \mu \mathrm{m}$ greatest width; holotype $5.0 \mu \mathrm{m}$ high, $5.7 \mu \mathrm{m}$ wide.

Holotype: USNM 256057 (Plate 9, Figures 4-6).

Isotype: USNM 256058.

Type locality: Eastern Atlantic Ocean, Sample 397A-46-3, 58-59 cm (1394 m).

\section{Genus MICROSTAURUS Black, 1971}

Remarks: The genus Microstaurus differs from the genus Helenea Worsley, 1971, in the mode of construction of the distal shield. Grun and Allemann (1975) note that the interelemental sutures on the distal shield of Microstaurus are radial, while those on Helenea are sickleshaped. Although both genera have been observed in Hole 397A samples on the SEM, it is not known if it is possible to distinguish between them on the light microscope. The shield construction of Cruciellipsis cuvillieri is similar to that of Microstaurus, but Cruciellipsis has crossbars constructed of long narrow elements and may bear a long stem. Crossbars and stems of both Microstaurus and Helenea are constructed of small, nearly equidimensional crystals. When well-preserved, Cruciellipsis cuvillieri, as emended herein, may possess thin crystalline bars bridging the gap between the crossbars and the rim. This feature has not been observed in specimens of Microstaurus and Helenea from the same sample.

\section{Microstaurus chiastius (Worsley, 1971) Grun, 1975} (Plate 6, Figure 1)

Helenea chiastia Worsley, 1971, p. 1310, pl. 1, fig. 42-44.

Microstaurus quadratus Black, 1971a, p. 404, pl. 32, fig. 2.

Cruciellipsis cuvillieri (Manivit, 1966) Wilcoxon, 1972 (partim), p. 431 , pl. 4 , fig. 3 (non fig. 4).

Microstaurus chiastius (Worsley, 1971) Grün in Grün and Allemann, 1975, p. 181, text-fig. 22, pl. 5, fig. 1-4.

Cretarhabdus quadratus (Black, 1971) Wind, 1978, p. 764 , pl. 1, fig. 8, 9 .

Remarks: This species is distinguished from Microstaurus conus (Worsley, 1971) Wind and Cepek, n. comb., by its smaller size and blocky stem. The crossbars of $M$. conus are much brighter in crosspolarized light than those of $M$. chiastius.
Grün and Allemann (1975) place Cruciellipsis chiastia (Worsley) Thierstein (in Roth and Thierstein, 1972) in synonymy with Helenea staurolithina Worsley, 1971.

Occurrence: This species is known from the Berriasian through Hauterivian. It is a rare nannofloral element in Hole 397A.

Microstaurus conus (Worsley, 1971) Wind and Čepek, n. comb. (Plate 6, Figures 2, 3)

Staurolithites? conus Worsley, 1971, p. 1313, pl. 2, fig. 17-19.

Description: Large rhabdolith with broad central area spanned by crossbars supporting a long stem. Crossbars widen as they approach the rim. A suture bisecting each crossbar into parallel and symmetrical elements is visible in both phase contrast and cross-polarized light.

Remarks: This species appears to be constructed of radial distal shield elements, and is therefore placed in Microstaurus rather than in Helenea. It is larger and generally more circular than Microstaurus chiastius, and bears a longer narrow stem.

Occurrence: This species is present in the Valanginian to Hauterivian of DSDP Hole 5A and Hole 397A.

Size: Maximum diameter between 8.0 and $10.2 \mu \mathrm{m}$.

$$
\begin{gathered}
\text { Genus OCTOPODORHABDUS Noël, 1965, } \\
\text { emend. Wind and Čepek } \\
\text { (= Octocyclas Black, 1972) }
\end{gathered}
$$

Description: Large podorhabdid with eight or more large perforations in one or more cycles surrounding a central stem. The central area is dominated by large perforations. When eight windows are present, they are situated in a generally symmetrical configuration around the outer portion of the central area. Specimens with more than eight perforations may have the windows on several levels surrounding the central stem, and the deployment of perforations is not symmetrical with respect to the axes of the ellipse.

Remarks: The type series, Octopodorhabdus praevisus Noël, 1965 , consists of eight perforations, two of which are on the long axis of the ellipse. Octopodorhabdus decussatus (Manivit) Rood, Hay, and Barnard, 1971, has eight large windows defined by thin buttresses which are generally subparallel to the ellipse axes. Although Black (1972, p. 38 ) notes that the eight large windows in Octocyclas magnus (= Octopodorhabdus decussatus) are arranged symmetrically about the major buttresses, and that these buttresses lie along the principal axes of the ellipse, several of the specimens illustrated (especially Black, 1972, pl. 8, fig. 1-5) have an asymmetrical buttress and window configuration.

The main differences between Octopodorhabdus and Hexapodorhabdus are in size of the coccolith, and dimensions and arrangement of central area perforations. Specimens of Hexapodorhabdus (and Perissocyclus Black, 1971) are generally between 5.0 and $7.0 \mu \mathrm{m}$ in greatest diameter, while those of Octopodorhabdus are usually greater than $10.0 \mu \mathrm{m}$ in greatest dimension. Central area windows in Octopodorhabdus are large and rounded, while the perforations in other genera are small and angular.

\section{Octopodorhabdus plethotretus Wind and Čepek, n. sp.} (Plate 4, Figures 1-5)

non Zygolithus fenestratus Stover, 1966, p. 147, pl. 3, fig. 21, 22, pl. 4, fig. 1, pl. 8, fig. 24.

Perissocyclus fenestratus (Stover) Black, 1971a, p. 406, pl. 32, fig. 4.

Description: A species of Octopodorhabdus with two or more cycles of large perforations in the inner area. More than eight perforations surround the stem in the central area. Most windows are located in a single cycle along the outer edge of the central area and around the base of the stem. Additional windows may be present between the outer cycle and the set of four which ring the stem. Buttresses supporting the stem and delineating the central area perforations may or may not be positioned in a symmetrical fashion with respect to the axes of the ellipse.

Remarks: The species name is from the Greek plethos $=$ great number; tretos $=$ perforated. This species is distinguished from $O c$ topodorhabdus decussatus (Manivit) by its greater number of perforaforations (Hexapodorhabdus Noël, 1965) or eight perforations (Octospecimen illustrated in Black (1971a) is quite similar both in size and general appearance to many specimens from Hole 397A. The forms 
illustrated in Stover (1966) demonstrate a non-podorhabdid rim construction especially in cross-polarized light; these forms are probably related to the genus Cretarhabdus. Some specimens, such as those illustrated in Plate 4, Figure 4, and in Black (1971a, pl. 32, fig. 4) have central area windows whose general size and positioning with respect to the rim resembles corresponding features on specimens of Perissocyclus noëliae Black, 1971, emend. Wind and Čepek.

On the light microscope, it is often difficult to identify central area perforations other than those of the outer cycle. The four inner windows of the holotype were not known to exist until the specimen was transferred to the SEM.

Occurrence: This species is fairly common in well-preserved samples from the Hauterivian of Hole $397 \mathrm{~A}$, and is present in the Barremian of England.

Size: Maximum length 9.8 to $11.8 \mu \mathrm{m}$. Holotype $11.0 \mu \mathrm{m}$.

Holotype: USNM 256046 (Plate 4, Figures 1-3).

Isotypes: USNM 256047, 256048.

Type locality: Eastern Atlantic Ocean, Sample 397A-46-3, 58-59 cm (1394 m).

\section{Genus PARHABDOLITHUS Deflandre, 1952}

\section{Parhabdolithus asper (Stradner, 1963) Manivit, 1971 (Plate 5, Figure 4)}

Remarks: The well-developed sculpturing on the distal surface of some specimens illustrated by Roth and Thierstein (1972, pl. 7, fig. 8-11) was not observed on specimens from Hole 397A. Forms placed in this species were distinguished from Parhabdolithus splendens by their less elongated oval shape and the often-present bright ring outlining a central perforation.

Occurrence: Early Berriasian to late Turonian.

\section{Parhabdolithus eboracensis (Black, 1971) \\ Wind and Cepek, n. comb.}

(Plate 5, Figures 11-13)

Rhagodiscus eboracensis Black, 1971a, p. 419, pl. 33, fig. 9.

Description: Elliptical form with broad rim surrounding a central area paved by an unordered field of small crystallites. No central perforation is present.

Remarks: Black (1971a) distinguished this species from Parhabdolithus asper (Stradner) by the much greater thickness of the wall (we question this conclusion) and the lack of any perforations or geometric pattern in the central area. This form is nearly invisible in phase contrast, and only the rim is discernible in cross-polarized light.

Occurrence: This species present in the Hauterivian of England and the Hauterivian of Hole 397A.

Size: Generally between 5.3 and $7.0 \mu \mathrm{m}$ in greatest dimension.

\section{Parhabdolithus judithae Black, 1972}

(Plate 11, Figures 5-7)

Parhabdolithus judithae Black, 1972, p. 30-31, pl. 3, fig. 5, 6; pl. 4, fig. 4.

Description: Thick, elliptical base supporting a broad, thicknecked hollow stem. The flat-topped stem occupies nearly all of the distal surface of the base. Crystal elements of the stem exhibit a characteristic gyre in cross-polarized light (see Plate 11, Figure 7).

Remarks: Several specimens observed in lateral view appear to be identical to the forms illustrated in Black (1972). The general proportions of the stem and base suggest that Parhabdolithus judithae represents an intermediate form between P. swinnertonii (Black) and ?Parhabdolithus sp.

Occurrence: Late Albian of England, and Hauterivian of Hole 397A.

\section{Parhabdolithus swinnertonii (Black, 1971) Wind and Cepek, n. comb. \\ (Plate 11, Figures 8-16)}

Rhabdolithina swinnertoni Black, 1971a, p. 418, pl. 34, fig. 4. Parhabdolithus boletiformis Black, 1972, p. 29-30, pl. 3, fig. 3, 4; pl. 4, fig. 1-3.
Description: Elliptical rhabdolith with thick base and bulbous, distally projecting stem. The base may be as thick as $2.0 \mu \mathrm{m}$, constructed of highly inclined elements. The stem widens distally and consists of concentric tiers of erect crystallite laths. The stem is variable in size, occupying from $1 / 4$ to $3 / 4$ of the distal surface of the specimen.

Remarks: This form has previously been illustrated only with transmission electron micrographs; distal view in Black (1971a), lateral view in Black, 1972. Parhabdolithus swinnertonii has been observed in both orientations in Hole 397A samples, although specimens are only rarely seen in lateral view. $P$. swinnertonii is distinguished from other stemmed species of Parhabdolithus by the geometry and size of the stem. We do not know whether the presence or absence of inflated stems in Valanginian-Hauterivian, Aptian, and Albian parhabdolithids is a valid paleontological feature, or one which simply reflects the quality of preservation. The construction of the inflated stem suggests that it would be much more susceptible to dissolution and fragmentation than the highly imbricate, robust base.

Occurrence: Late Aptian (Black, 1971a), middle Albian (Black, 1972), and Hauterivian (Hole 397A).

\section{?Parhabdolithus sp. \\ (Plate 11, Figures 1-4)}

Description: Hollow, inflated stem arising from a narrow basal rim. Crystallites constructing the bulbous stem project upward in a counterclockwise direction with respect to the base.

Remarks: Although not a typical parhabdolithid, this form appears to be related to this genus because of the similarity of construction with that of Parhabdolithus judithae Black. This form is distinguished from Laguncula dorotheae Black by the broader neck where it is attached to the basal plate.

Occurrence: Rare in samples from the Hauterivian of Hole 397A.

\section{Genus PERISSOCYCLUS Black, 1971}

Remarks: Black (1971a) proposed the genus Perissocyclus for elliptical coccoliths with a podorhabdid rim surrounding a wide central area with a hollow spine and one or two concentric cycles of perforations. Black (1971a, p. 405) noted that coccoliths of this genus differ from other podorhabdids in the particular freedom with which their windows are arranged. Members of this genus may be descendants of the Jurassic genus Hexapodorhabdus Noel, 1965. Forms placed in Octopodorhabdus ( = Octocyclas Black, 1972) are generally much larger, with larger windows and thinner crossbars.

\section{Perissocyclus noeliae Black, 1971 emend. Wind and Čepek}

(Plate 4, Figures 6-12)

Perissocyclus noelae Black, 1971a, p. 405-406, pl. 32, fig. 6 . Perissocyclus fletcheri Black, 1971a, p. 406-407, pl. 32, fig. 3.

Description: Small podorhabdid with five or more small perforations in one or two cycles surrounding a hollow stem in the central area. Specimens may be elliptical or may have greater curvature on one portion of the rim parallel to the long axis.

Remarks: Perissocyclus noeliae Black, 1971, was defined as having a single cycle of from five to nine windows, while $P$. fletcheri Black, was described as a form having 10 to 16 windows in one or two cycles. Hauterivian specimens from Hole 397A have between 9 and 18 perforations. The size of the entire specimen and width of the individual holes is related to the number of holes present. As illustrated in Plate 4 , specimens with 9 or 10 holes are between 5.5 and $6.0 \mu \mathrm{m}$ in length, while those with 12 or more holes approach $7.0 \mu \mathrm{m}$ in greatest dimension. Only rare specimens with a second cycle of holes were observed on the light microscope and SEM.

This species represents a departure from the more rigid morphological framework of Late Jurassic podorhabdids, defined by six perforations (Hexapodorhabdus Noel, 1965) or eight perforations (Octopodorhabdus Noel, 1965). We reserve the genus Polypodorhabdus Noèl, 1965, for forms with elongate parallel perforations as in Polypodorhabdus escaigii Noel, 1965.

Occurrence: Berriasian and Hauterivian of England, and Hauterivian of Hole 397A. 


\section{Genus RHABDOLEKISKUS Hill, 1976}

Rhabdolekiskus parallelus Wind and Čepek, n. sp. (Plate 3, Figures 3-6)

Eurhabdus luciformis Reinhardt, 1965 - Wilcoxon, 1972a, pl. 10, fig. 4.

Description: Long, straight-sided stem constructed of four elongate elements arising from a small tabular base. Width of stem is about half of the width of the base.

Remarks: The mode of construction of the base and stem of this species is best illustrated in Plate 3, Figure 6, and in Wilcoxon (1972a, pl. 10, fig. 4), consisting of a thin single cycle of flat-lying elements supporting a taller set of inclined tablets. The constant width of the stem of this species distinguishes it from Rhabdolekiskus aquitanius (Manivit, 1971) Hill, 1976, which tapers both towards its terminus and towards the point of attachment of base and stem. The specimen illustrated in Wilcoxon (1972a) is approximately the same size as the specimens illustrated in Plate 3. Eurhabdus luciformis Reinhardt is a much larger form which was placed in synonymy with Lucianorhabdus cayeuxii Deflandre in Wind (1975).

Occurrence: This species is present in several well-preserved Hauterivian samples from Hole 397A, and is also present in the Barremian of Hole 105 (western North Atlantic).

Size: Total length to $9.8 \mu \mathrm{m}$ : Holotype $8.5 \mu \mathrm{m}$. Width of base 2.0 to $2.4 \mu \mathrm{m}$ : Holotype $2.0 \mu \mathrm{m}$. Width of stem 0.85 to $1.0 \mu \mathrm{m}$ : Holotype $0.92 \mu \mathrm{m}$.

Holotype: USNM 256043 (Plate 3, Figure 3).

Isotypes: USNM 256044, 256045.

Type locality: Eastern Atlantic Ocean, Sample 397A-47, CC $(1405 \mathrm{~m})$.

\section{Genus TRAPEZOPENTUS Wind and Čepek, n. gen.}

Type species Trapezopentus sarmatus

Wind and Cepek, n. gen., n. sp.

Description: Pentalith constructed of overlapping trapezoidal elements surrounding a large central opening.

Remarks: The name of the genus is derived from the Greek Trapezion $=4$-sided; Penta $=$ five. This genus is distinguished from Braarudosphaera and Micrantholithus by the presence of a large central opening. Braarudosphaera and Micrantholithus are constructed of five generally triangular plates which meet at or near a central point. Overlapping of adjacent elements is sometimes observed in these latter genera. On the light microscope, sutures of Trapezopentus are not radial, as in other pentaliths, but appear as continuations of the inner margin of component elements. Forms placed in Trapezopentus cannot be viewed as dissolved specimens of Braarudosphaera or Micrantholithus, as dissolution would be expected to disarticulate pentaliths rather than enlarge a central area perforation.

Trapezopentus sarmatus Wind and Cepek, n. sp.

(Plate 2, Figures 1-5)

Description: Pentalith with straight or slightly concave sides and sharp or slightly rounded corners. The open center constitutes approximately half of the area of the pentalith.

Remarks: The species name is from the Greek Sarmatus $=$ chasm in the earth. Goniolithus fluckigeri Deflandre, 1957 (Oligocene) also appears as an open pentalith, but the five narrow plates surround a thin inner area mineralized pavement and the surrounding plates do not overlap. Specimens of Braarudosphaera hockwoldensis Black, 1973, possess a small pentagonal perforation at the center formed by the misalignment of the five plates.

No specimens were observed with central area perforations appreciably smaller than those illustrated by the holotype and isotype. All specimens of Micrantholithus obtusus Stradner (= Braarudosphaera hoschulzii Reinhardt) (Thierstein, 1976) have solid centers, and when plate thinning is observed, it is always found along the outer margin of the pentalith.

Specimens illustrated in Plate 2, Figures 6-8, identified as $T$. sp. aff. $T$. sarmatus are distinguished by a slightly smaller size and more circular periphery.

Occurrence: This species has only been observed in the Hauterivian sediments from DSDP Hole 397A.

Size: 8.0-10.0 $\mu \mathrm{m}$ maximum diameter; Holotype $9.5 \mu \mathrm{m}$.
Holotype: USNM 256039 (Plate 2, Figure 1).

Isotypes: USNM 256040, 256041.

Type locality: Eastern Atlantic Ocean, Sample 397A-46-3, 58-59 cm (1394 m).

\section{Genus WATZNAUERIA Reinhardt, 1964}

Remarks: In this report, we do not recognize the division between the genera Watznaueria and Ellipsagelosphaera as proposed by PerchNielsen (1968) and followed by Grun and Allemann (1975). Those researchers distinguishing these two groups by the absence or presence of a central area tube cycle would place the following species in the latter genus.

Watznaueria fasciata Wind and Čepek, n. sp. (Plate 7, Figures 5, 6)

?Ellipsagelosphaera ovata (Bukry, 1969) Black, 1973, pl. 26, fig. 10 (non fig. 11, 12).

?Ellipsagelosphaera ovata (Bukry, 1969) Black, 1973-Grün and Allemann, 1975, p. 160-161, fig. 6, pl. 2, fig. 8 (non fig. 7, 9).

Description: Small elliptical species of Watznaueria with a twocycle distal shield and central tube. The elliptical central area is spanned by five bars of blocky crystals aligned parallel to the short axis of the placolith. The crossbars fill about half of the central area. The inner cycle of distal rim elements is approximately half the width of the outer cycle.

Remarks: The species name is from the Latin fasciatus = banded, striped. This form is distinguished from other species of Watznaueria by its small size and the presence of several distinct crossbars in the central area. All six specimens examined on the scanning electron microscope contain five central area crossbars. Although the central area bars are not discernible in phase contrast or cross-polarized light, this species can be identified on the light microscope by its small size and the dimensions of the central area.

The stratigraphic range of this species is not known. The apparent weakness of the attachment of the crossbars to the central area tube cycle (see Plate 7, Figures 5,6) suggests that these structures may be easily removed if samples are subjected to even minor dissolution, and in such instances, these forms would resemble Watznaueria ovata Bukry, 1969. The shield cycles of Watznaueria fasciata are of unequal width, while those of the holotype of $W$. ovata are of approximately equal size. One specimen of $E$. ovata (Bukry) in Grun and Allemann (1975, pl. 2, fig. 8) from the Berriasian of Spain has the same general size and shield configuration as specimens of $W$. fasciata.

Occurrence: Common in the Hauterivian of Hole 397A. This species appears to also be present in the Berriasian of Spain and the Hauterivian of DSDP Hole 5A. It may also be present in the Albian of England.

Size: Maximum diameter 3.9 to $4.5 \mu \mathrm{m}$ : Holotype $4.0 \mu \mathrm{m}$.

Holotype: USNM 256049 (Plate 7, Figure 5).

Isotype: USNM 256050.

Type locality: Eastern Atlantic Ocean, Sample 397A-46-3, 58-59 cm (1394 m).

\section{REFERENCES}

Barnard, T. and Hay, W.W., 1974. On Jurassic coccoliths: A tentative zonation of the Jurassic of southern England and north France, Eclogae Geologicae Helvetiae, v. 67, p. 563-585.

Black, M., 1971a. Coccoliths of the Speeton Clay and Sutterby Marl, Proceedings of the Yorkshire Geological Society, v. 38 , p. $381-424$.

1971b. Problematical microfossils from the Gault Clay, Geological Magazine, v. 96, p. 325-327.

1972. British Lower Cretaceous coccoliths. I. Gault Clay (Part 1), Palaeontographical Society (Monographs), p. 1-48.

1973. British Lower Cretaceous coccoliths. I. Gault Clay (Part 2), Palaeontographical Society (Monographs), p. 49-112.

1975. British Lower Cretaceous coccoliths. I. Gault Clay (Part 3), Palaeontographical Society (Monographs), p. 113-142. 
Brönnimann, P., 1955. Microfossils incertae sedis from the Upper Jurassic and Lower Cretaceous of Cuba, Micropaleontology, v. 1, p. 28-51.

Bukry, D., 1969. Upper Cretaceous coccoliths from Texas and Europe, University of Kansas Paleontological Contributions, Article 51 (Protista 2), p. 1-79.

Bukry, D. and Bramlette, M.N., 1969. Coccolith age determiations Leg 1, Deep Sea Drilling Project. In Ewing, M., et al., Initial Reports of the Deep Sea Drilling Project, v. 1: Washington (U.S. Government Printing Office), p. 369-387.

Čepek, P., 1970. Zur Vertilcalverbreitung von coccolithen Arten in der Oberkreide NW-Deutschlands, Geol. Jb., v. 88 , p. $235-264$.

1978. Mesozoic calcareous nannoplankton of the eastern North Atlantic, Leg 41. In Lancelot, Y., Seibold, E., et al., Initial Reports of the Deep Sea Drilling Project, v. 41: Washington (U.S. Government Printing Office), p. 667-688.

Deflandre, G., 1957. Goniolithus nov. gen., type d'une famille nouvelle de Coccolithophorides fossiles, a elements pentagonaux non composites, Comptes rendus de l'Academie Science Paris, v. 244, p. 2539-2541.

Deflandre, G. and Fert, C., 1954. Observations sur les coccolithophorides actuels et fossiles en microscopie ordinaire et electronique, Annales de Paleontologie, v. 40, p. 115-176.

Grün, W. and Allemann, F., 1975. The Lower Cretaceous of Caravaca (Spain) Berriasian calcareous nannoplankton of the Miravetes Section (Subbetic Zone, Prov. of Murcia), Ecologae Geologicae Helvetiae, v. 68, p. 147-211.

Hill, M.E., III, 1976. Lower Cretaceous calcareous nannofossils from Texas and Oklahoma, Sonder-Abdruck aus Palaeontographica Beitrage zur naturgeschichte der Vorzeit, Band 156, p. 103-179.

Noël, D., 1965. Sur les coccolithes du Jurassique European et d'A frique du nord - Essai de classisification des coccolithes fossiles: Paris (Editions du Centre National de la Recherche Scientifique), p. 1-206.

1973 (1972). Nannofossiles calcaires de sediments Jurassiques finement lamines, Museum National d'Histoire Naturelle Bulletin, v. 75, p. 95-155.

Proto Decima, F., 1974. Leg 27 calcareous nannoplankton. In Veevers, J.J., Heirtzler, J.R., et al., Initial Reports of the Deep Sea Drilling Project, v. 27: Washington (U.S. Government Printing Office), p. 589-621.

Risatti, J.B., 1973. Nannoplankton biostratigraphy of the Upper Bluffport Marl - Lower Prairie Bluff Chalk interval (Upper Cretaceous), in Mississippi. In Smith, L.A. and Hardenbol, J. (Eds.), Proceedings of Symposium on Calcareous Nannofossils: Houston (Gulf Coast Section Society of Economic Paleontologists and Mineralogists), p. 8-57.

Rood, A.P., Hay, W.W., and Barnard, T., 1971. Electron microscope studies of Oxford Clay coccoliths, Eclogae Geologicae Helvetiae, v. 64, p. 245-272.

Roth, P., 1973. Calcareous nannofossils - Leg 17, Deep Sea Drilling Project. In Winterer, E.L., Ewing, J.L., et al., Initial Reports of the Deep Sea Drilling Project, v. 17: Washington (U.S. Government Printing Office), p. 695-795.
Roth, P.H. and Thierstein, H., 1972. Calcareous nannoplankton: Leg 14 of the Deep Sea Drilling Project. In Hayes, D.E., Pimm, A.C., et al., Initial Reports of the Deep Sea Drillng Project, v. 14: Washington (U.S. Government Printing Office), p. 421-485.

Sissingh, W., 1977. Biostratigraphy of Cretaceous calcareous nannoplankton, Geologie en Mijnbouw, v. 56, p. 36-65.

Thierstein, H.R., 1971. Tentative Lower Cretaceous calcareous nannoplankton zonation, Eclogae Geologicae Helvetiae, v. 64 , p. $459-488$.

1973. Lower Cretaceous calcareous nannoplankton biostratigraphy, Abhandlungen der Geologischen Bundesanstalt, Band 29, 1-52. 1975. Calcareous nannoplankton biostratgraphy at the Jurassic-Cretaceous boundary, Memoires du Bureau de Recherches Geol. et Minieres, v. 86, p. 84-94. 1976. Mesozoic calcareous nannoplankton biostratigraphy of marine sediments, Marine Micropaleontology, v. 1 , p. $325-362$.

Trejo, M., 1960. La Familia Nannoconidea y su alcance estratigrafico en America. (Protozoa, Incertae saedie), Boletin de la Mexicana de Geologos Petroleros, v. 12, p. 259-314.

1969. Conusphaera mexicana, un nuevo coccolitoforido del Jurasico superior de Mexico, Rev. Inst. Mexicano del Petroleo, v. 1, p. 5-15.

Verbeek, J.W., 1976. Upper Cretaceous calcareous nannoplankton from Ballon and Theligny, in the type area of the Cenomanian Stage (Sarthe, France), Proceedings of the Koninkl. Nederl. Akademie van Wetenschappen, v. 79, p. 69-82.

Wilcoxon, J. A., 1972a. Upper Jurassic-Lower Cretaceous nannoplankton from the Western North Atlantic Basin. In Hollister, C.D., Ewing, J.I., et al., Initial Reports of the Deep Sea Drilling Project, v. 11: Washington (U.S. Government Printing Office), p. 427-458.

1972b. Calcareous nannoplankton ranges, Leg XI, Deep Sea Drilling Project. In Hollister, C.D., Ewing, J.I., et al., Initial Reports of the Deep Sea Drilling Project, v. 11: Washington (U.S. Government Printing Office), p. 459-474.

Wind, F.H., 1978. Western North Atlantic Upper Jurassic calcareous nannofossil biostratigraphy. In Benson, W.E., Sheridan, R.E., et al., Initial Reports of the Deep Sea Drilling Project, v. 44: Washington (U.S. Government Printing Office), p. 761-774.

Wind, F.H. and Wise, S.W., 1978. Mesozoic holococcoliths, Geology, v. 6, p. 140-142.

Wise, S.W. and Wind, F.H., 1977. Mesozoic and Cenozoic calcareous nannofossils recovered by DSDP Leg 36 drilling on the Falkland Plateau, southwest Atlantic sector of the Southern Ocean. In Barker, P.F., Dalziel, I.W.D., et al., Initial Reports of the Deep Sea Drilling Project, v. 36: Washington (U.S. Government Printing Office), p. 269-491.

Worsley, T.R., 1971. Calcareous nannofossil zonation of Upper Jurassic and Lower Cretaceous sediments from the western Atlantic. In Farinacci, A. (Ed.), Proceedings of the Second Planktonic Conference Roma, 1970: Rome (Edizioni Tecnoscienza), p. 1301-1321. 


\section{PLATE 1}

Figures 1-5 Bipodorhabdus colligatus (Black, 1971) Thierstein, 1976.

1,2. Scanning electron micrographs.

1. Distal view. Sample 397A-47, CC.

2. Proximal view. Sample 397A-41, CC.

3-5. Sample 397A-46-3, $58-59 \mathrm{~cm}$.

3. Phase contrast.

4,5. Cross-polarized light.

Figures 6-9 Calcicalathina oblongata (Worsley, 1971) Thierstein, 1971.

6,7. Scanning electron micrographs.

6. Lateral view. Sample 397A-41, CC.

7. Proximal-lateral view. Sample 397A-41, CC.

8,9 . Sample $397 \mathrm{~A}-46-3,58-59 \mathrm{~cm}$.

8. Phase contrast.

9. Cross-polarized light.

Figure 10 Nannoconus colomii (de Lapparent, 1931) Kamptner, 1938 (with Corollithion ellipticum Bukry, 1969). Scanning electron micrograph. Sample 397A-41, CC.

Figure $11 \quad$ Nannoconus sp.; scanning electron micrograph. Sample 397A-41, CC. 
PLATE 1
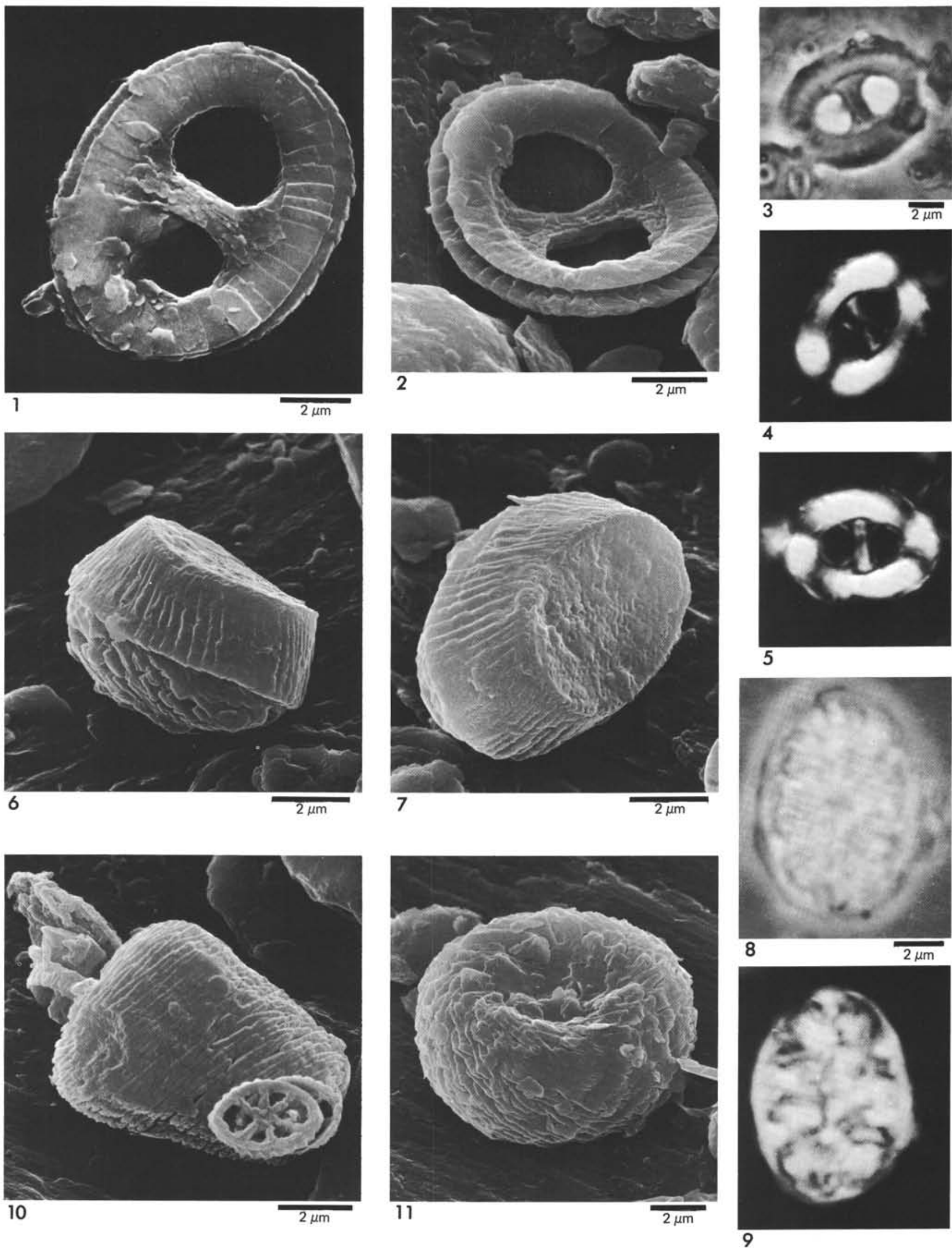


\section{PLATE 2}

Figures 1-5 Trapezopentus sarmatus Wind and Čepek, n. gen., n. sp.; Sample 397A-46-3, 58-59 cm.

1. Scanning electron micrograph; holotype; USNM 256039.

2,3. Isotype; USNM 256040.

2. Phase contrast.

3. Cross-polarized light.

4,5. Isotype; USUM 259041.

4. Phase contrast.

5. Cross-polarized light.

Figures 6-8 Trapezopentus sp. aff. T. sarmatus Wind and Čepek. Sample 397A-46-3, 58-59 cm.

6. Phase contrast.

7. Cross-polarized light.

8. Scanning electron micrograph.

Figures 9, 10 Micrantholithus obtusus Stradner, 1963. Sample 397A-47, CC.

9. Phase contrast.

10. Cross-polarized light.

Figures 11-13 Cruciellipsis cuvillieri (Manivit, 1966) Thierstein, 1971. emend. Wind and Čepek. Sample 397A-46-3, $58-59 \mathrm{~cm}$.

11. Phase contrast.

12. Cross-polarized light.

13. Scanning electron micrograph; distal view; hypotype; USNM 256042.

Figures 14, 15 Lithraphidites carniolensis Deflandre, 1963. Sample 397A-47, CC.

14. Cross-polarized light.

15. Phase contrast. 
PLATE 2
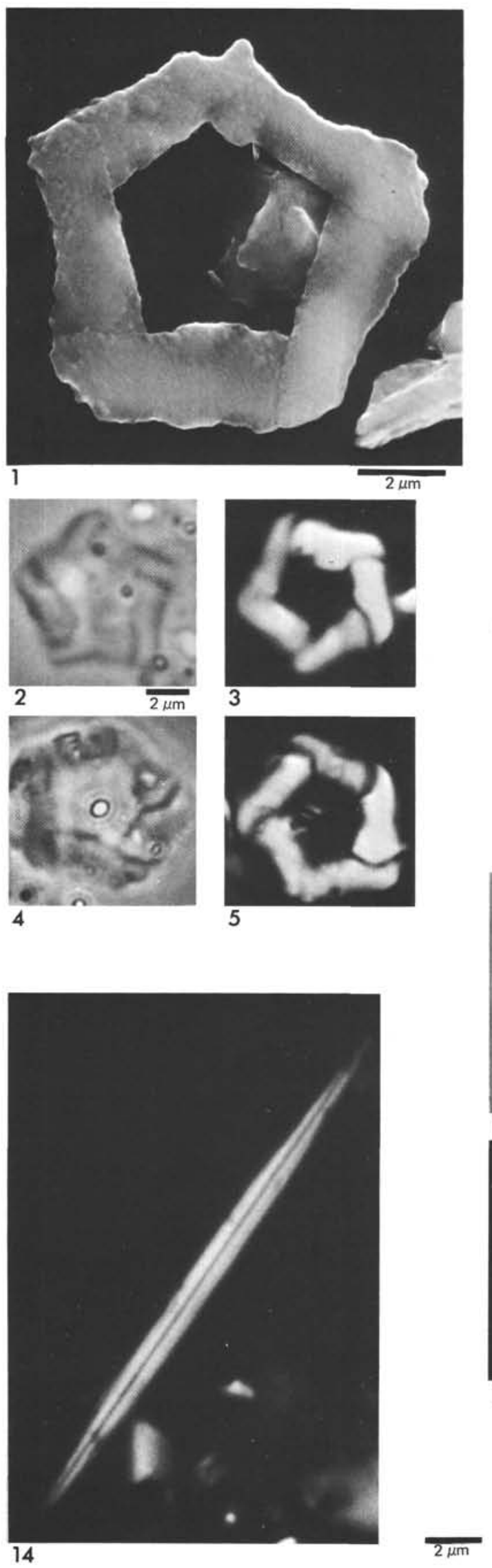
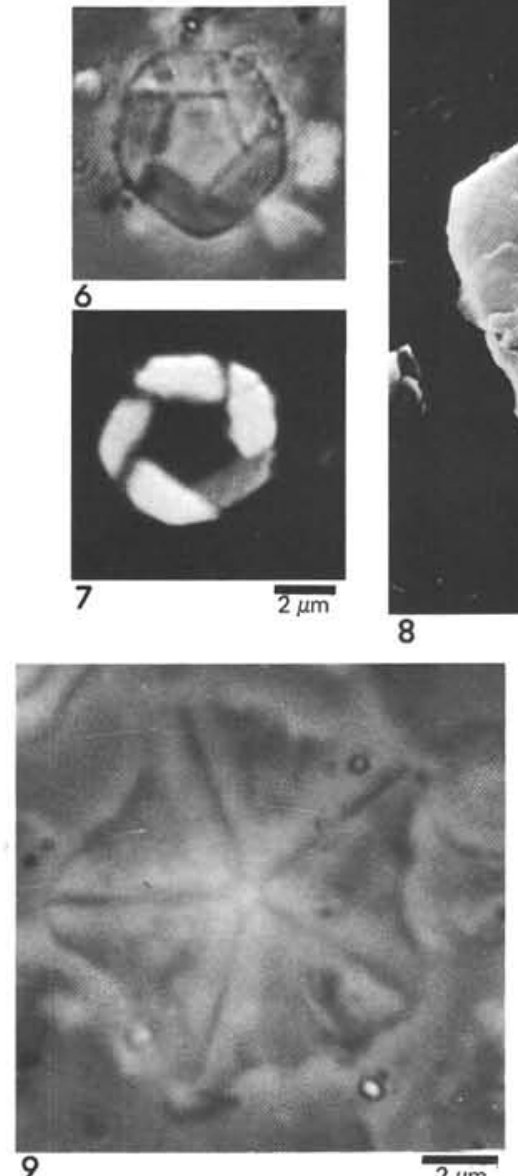

$2 \mu \mathrm{m}$

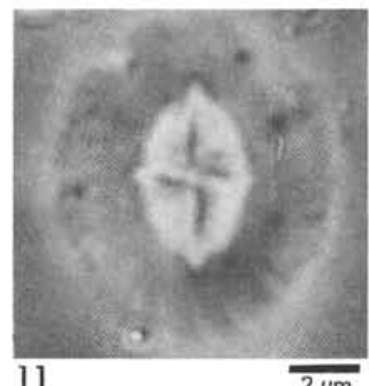

11
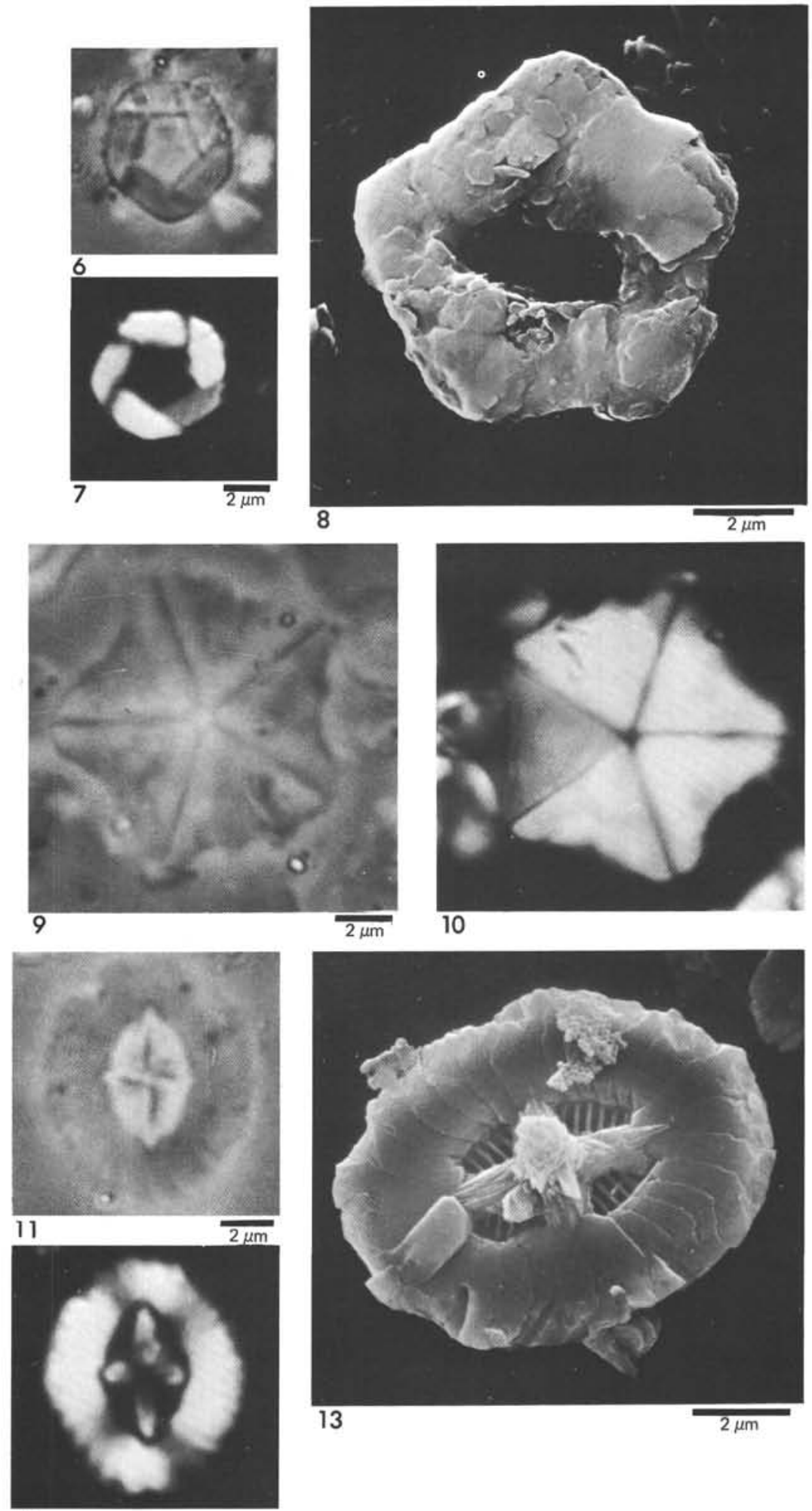

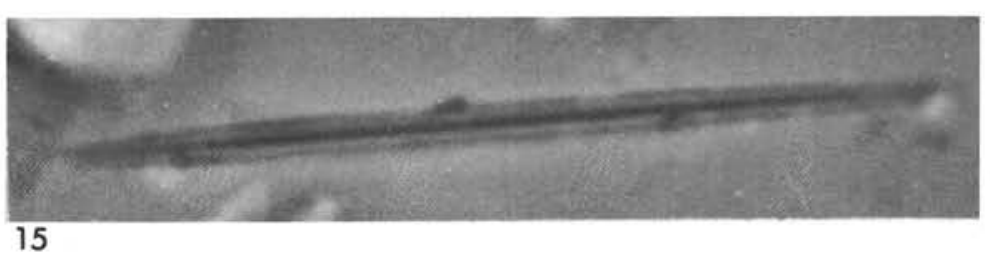




\section{PLATE 3}

Figures 1, 2 Stephanolithion laffittei Noël, 1957. Sample $397 \mathrm{~A}-47$, CC.

1. Scanning electron micrograph; distal-lateral view.

2. Phase contrast.

Figures 3-6 Rhabdolekiskus parallelus Wind and Cepek, n. sp.

3. Scanning electron micrograph; holotype USNM 256043; Sample 397A-47, CC.

4,5. Isotype USNM 256044. Sample 397A-46-3, $58-59 \mathrm{~cm}$.

4. Phase contrast.

5. Cross-polarized light.

6. Scanning electron micrograph; isotype USNM 256045; Sample 397A-39, CC.

Figures 7, 8 Diadorhombus rectus Worsley, 1971. Sample 397A-46, CC.

7. Phase contrast.

8. Cross-polarized light.

Figures 9-11 Rhabdolith with possible affinity to Diadorhombus rectus Worsley.

9,10. Sample 397A-46-3, $58-59 \mathrm{~cm}$.

9. Phase contrast.

10. Cross-polarized light.

11. Scanning electron micrograph; Sample 397A$41, \mathrm{CC}$.

Figures 12-17 ?Lithraphidites bollii (Thierstein, 1971) Thierstein, 1973. Sample 397A-47, CC.

$12,15,17$. Cross-polarized light.

$13,14,16$. Phase contrast. 
PLATE 3
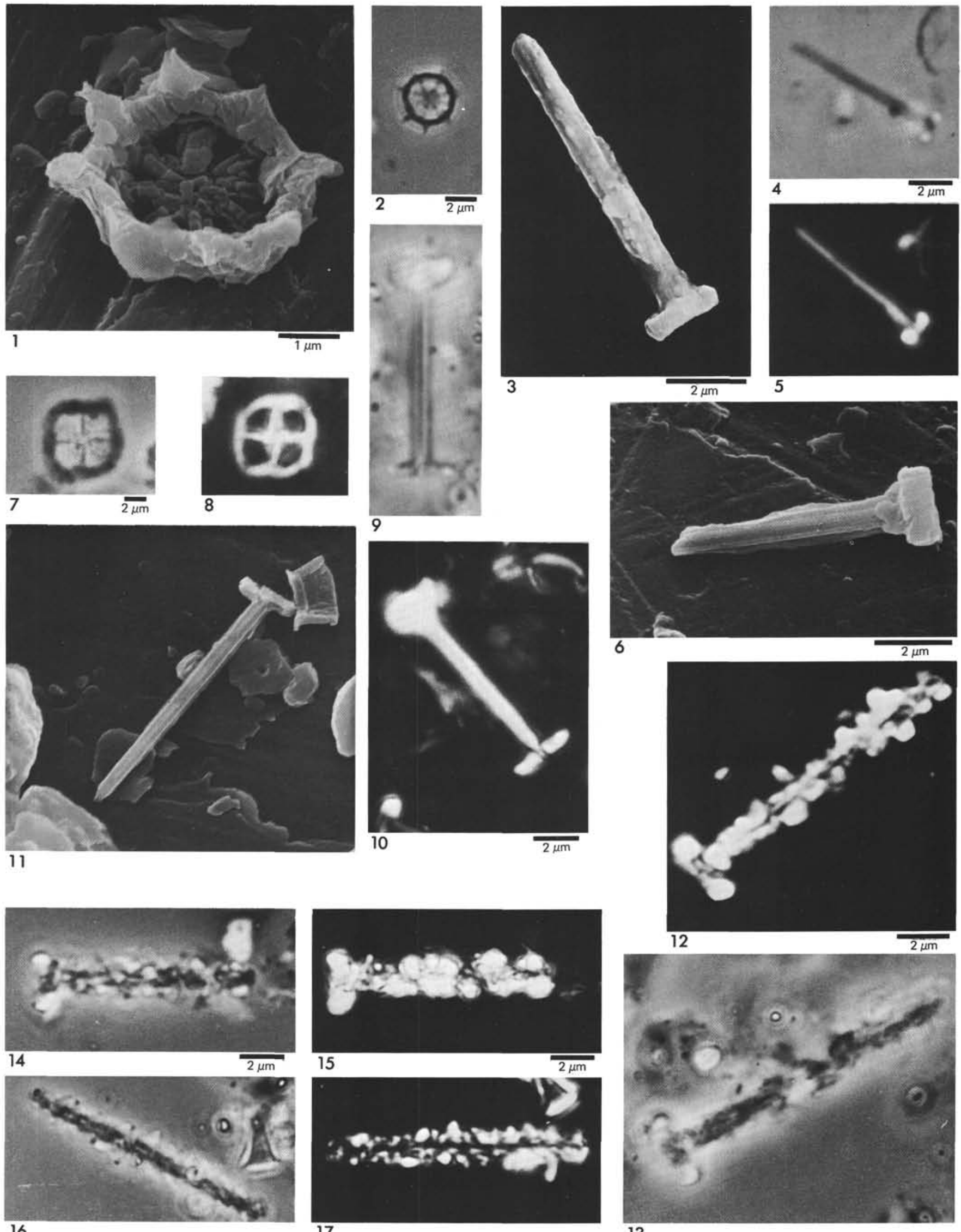


\section{PLATE 4}

Figures 1-5 Octopodorhabdus polytretus Wind and Čepek, n. sp. Sample 397A-46-3, $58-59 \mathrm{~cm}$.

1. Scanning electron micrograph; distal view; holotype, USNM 256046.

2,3. Same specimen as Figure 1.

2. Phase contrast.

3. Cross-polarized light.

4,5 . Scanning electron micrographs, distal views.

4. Isotype, USNM 256047.

5. Isotype USNM 256048.

Figures 6-12, Perissocyclus noeliae Black, 1971, emend. Wind 15, 16 and Cepek. Sample 397A-46-3, 58-59 cm.

6-9. Phase contrast.

10-12,15-16. Scanning electron micrographs; distal views.

Figures 13, 14 Axopodorhabdus cylindratus (Noel, 1965) Wind and Wise, 1977; Scanning electron micrographs. Sample 397A-41, CC.

13. Distal view.

14. Lateral view. 
PLATE 4
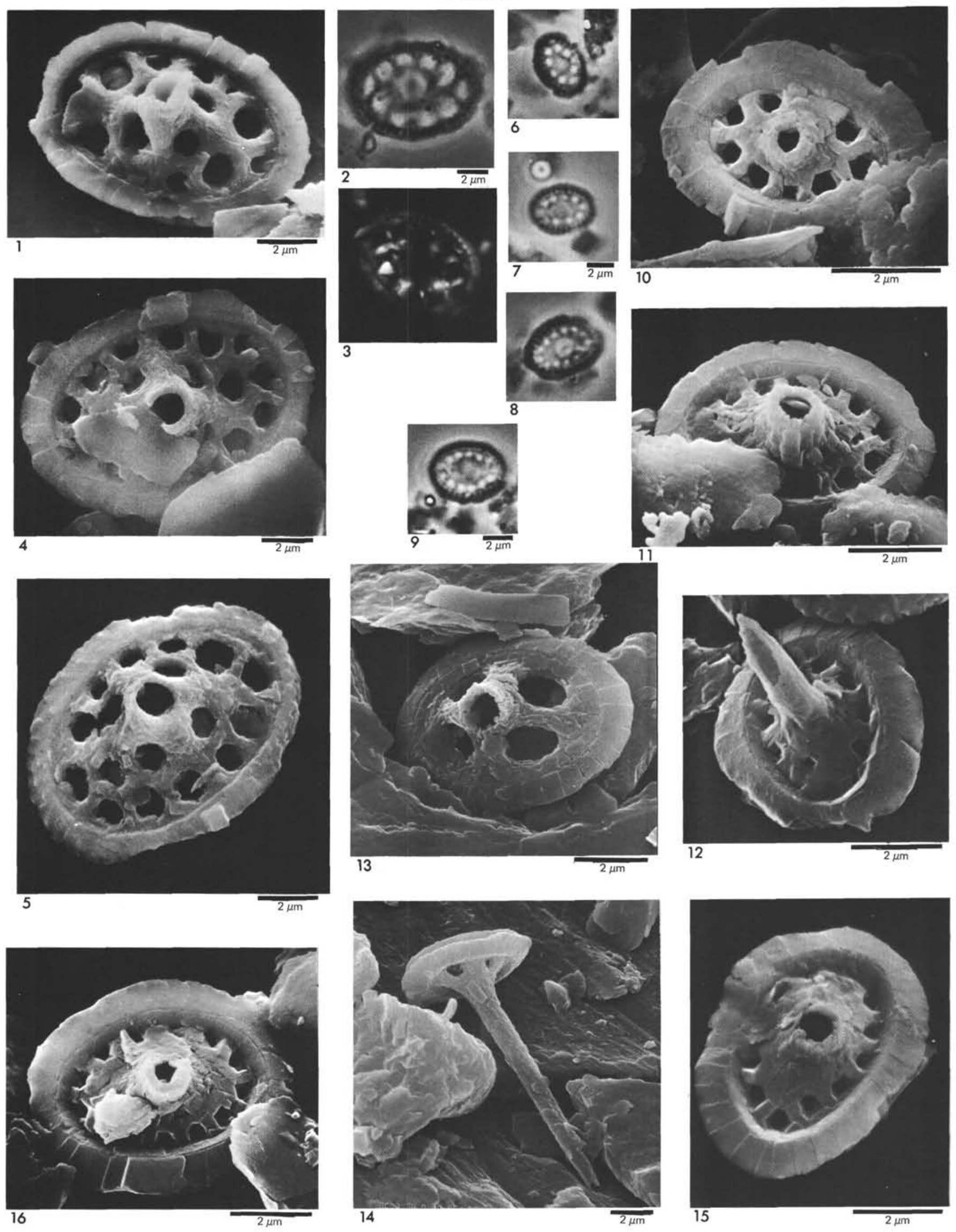


\section{PLATE 5}

Figures 1-3 Parhabdolithus infinitus (Worsley, 1971) Thierstein, 1972.

1. Scanning electron micrograph; distal view. Sample 397A-41, CC.

2,3. Sample $397 \mathrm{~A}-47, \mathrm{CC}$.

2. Phase contrast.

3. Cross-polarized light.

Figure $4 \quad$ Parhabdolithus asper (Stradner, 1963) Reinhardt, 1967. Scanning electron micrograph; distal view. Sample 397A-47, CC.

Figure $5 \quad$ Parhabdolithus splendens (Deflandre, 1954) Noel, 1969. Scanning electron micrograph; distal view. Sample 397A-46-3, 58-59 cm.

Figures 6-10 Discorhabdus sp. aff. D. biradiatus (Worsley, 1971) Thierstein, 1973. Sample 397A-41, CC.

6,7 . Scanning electron micrographs.

6. Distal view.

7. Lateral view.

8,9. Lateral view.

8. Phase contrast.

9. Cross-polarized light.

10. Proximal or distal view; cross-polarized light.

Figures 11-13 Parhabdolithus eboracensis (Black, 1971) Wind and Čepek, n. comb. Sample 397A-47, CC.

11. Phase contrast.

12. Cross-polarized light.

13. Scanning electron micrograph; distal view. 
PLATE 5
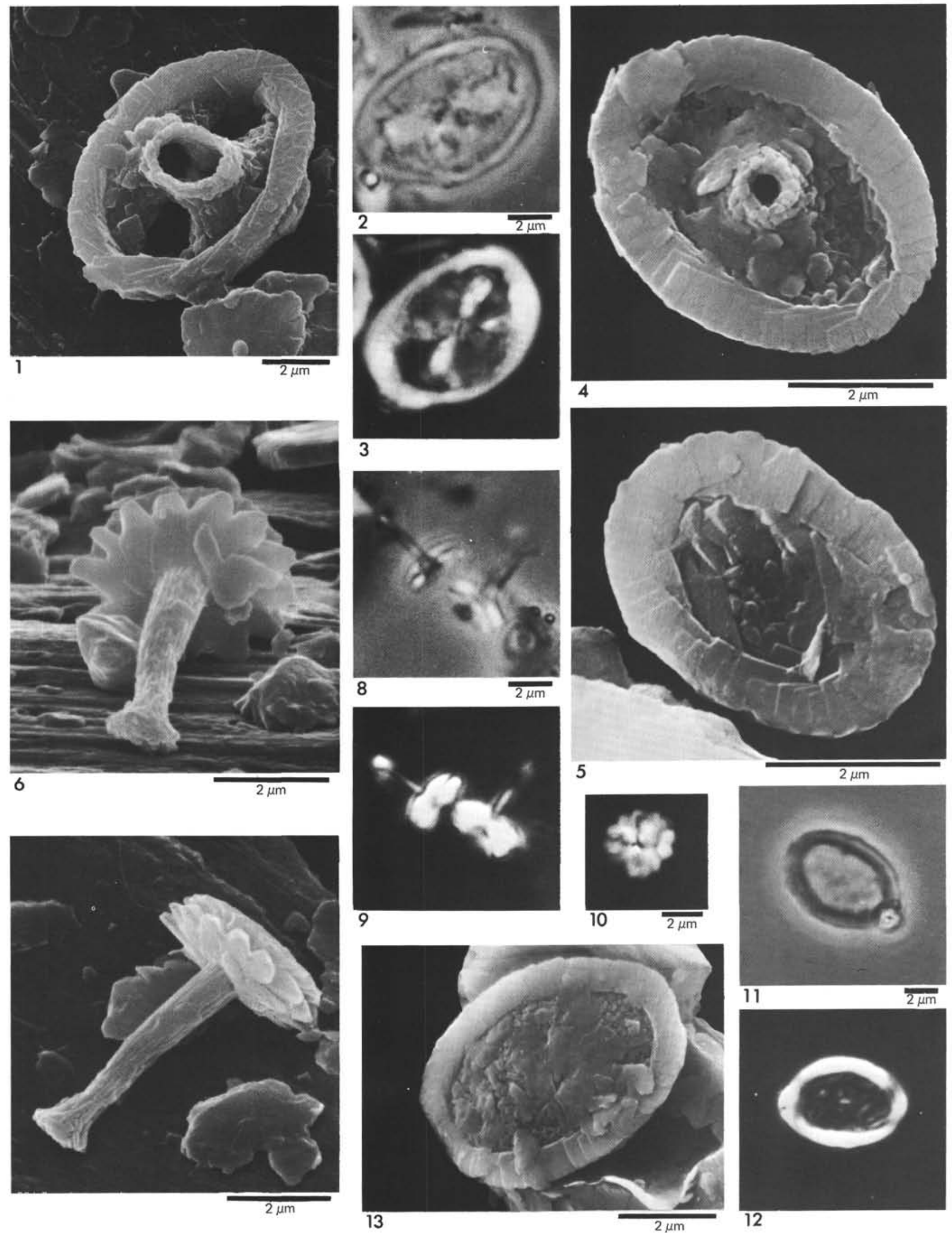


\section{PLATE 6}

Figure 1 Microstaurus chiastius (Worsley, 1971) Grün, 1975; Scanning electron micrograph, distal view. Sample 397A-46-3, 58-59 cm.

Figures 2, 3 Microstaurus conus (Worsley, 1971) Wind and Čepek, n. comb. Sample 397A-46-3, 58-59 cm.

2. Phase contrast.

3. Cross-polarized light.

Figures 4-6 Grantarhabdus meddii Black, 1971. Sample 3974-47, CC.

4. Phase contrast.

5,6. Cross-polarized light.

Figures 7-12 Ethmorhabdus gallicus Noël, 1965.

7,8. Sample 397A-46-3, $58-59 \mathrm{~cm}$.

7. Scanning electron micrograph; distal view.

8. Phase contrast; coated sample.

9,12. Samples 397A-47, CC.

9,10 . Phase contrast.

11,12. Cross-polarized light.

Figure 13 Diazomatolithus lehmanii Noël, 1965. Scanning electron micrograph; proximal view. Sample 397A-41, CC. 
PLATE 6
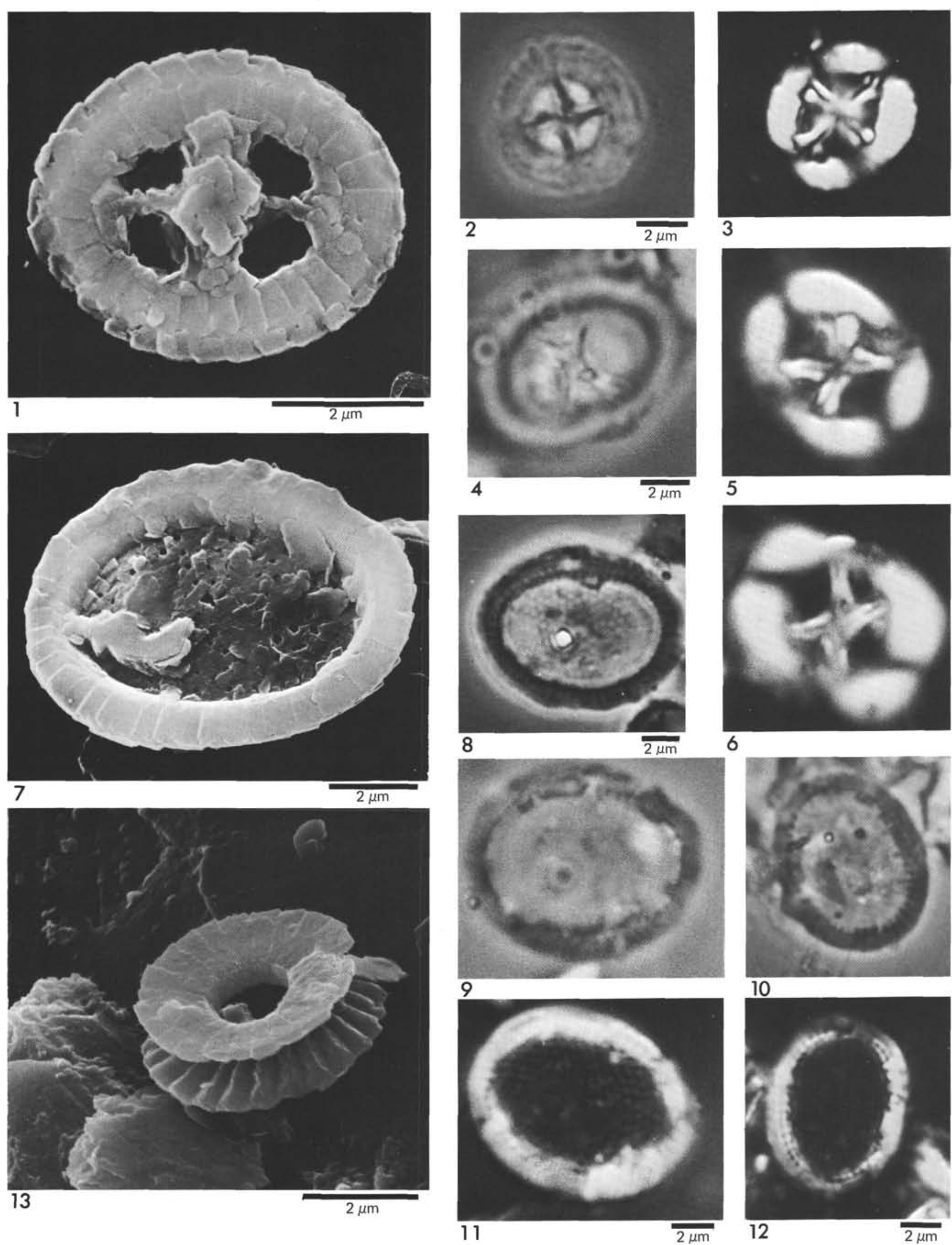


\section{PLATE 7}

Figures 1, 2 Corollithion ellipticum Bukry, 1969. Scanning electron micrographs.

1. On sediment grain, with Truncatoscaphus delftensis (Stradner and Adamiker, 1966) Rood, Hay and Barnard, 1971 (arrow); Sample 397A-41, CC.

2. On Nannoconus colomii (de Lapparent, 1931) Kamptner, 1938. (Detail of Plate 1, Figure 10); Sample 397A-41, CC.

Figures 3, 4 Conusphaera mexicana Trejo, 1969. Sample 397A-41, CC.

3. Phase contrast.

4. Cross-polarized light.

Figures 5, 6 Watznaueria fasciata Wind and Čepek, n. sp. Sample 397A-46-3, 58-59 cm. Scanning electron micrographs; distal views.

5. Holotype; USNM 256049.

6. Isotype; USNM 256050.

Figure $7 \quad$ Corollithion senarius Wind and Wise, 1977. Phase contrast; Sample 397A-47, CC.

Figures 8-11 ?Tetrapodorhabdus decorus (Deflandre and Fert, 1954) Wind and Wise, 1977; lateral views.

8,9 . Scanning electron micrographs.

8. Sample $397 \mathrm{~A}-46-3,58-59 \mathrm{~cm}$.

9. Sample 397A-47, CC.

10,11. Sample 397A-46-4, $22-23 \mathrm{~cm}$.

10. Phase contrast.

11. Cross-polarized light.

Figure $12 \quad$ Polypodorhabdus escaigii Noel, 1965; scanning electron micrograph; distal view. Sample 397A$46-3,58-59 \mathrm{~cm}$.

Figure 13 Zeugrhabdotus noeliae Rood, Hay, and Barnard, 1971; scanning electron micrograph; distal view; Sample 397A-39, CC. 
PLATE 7
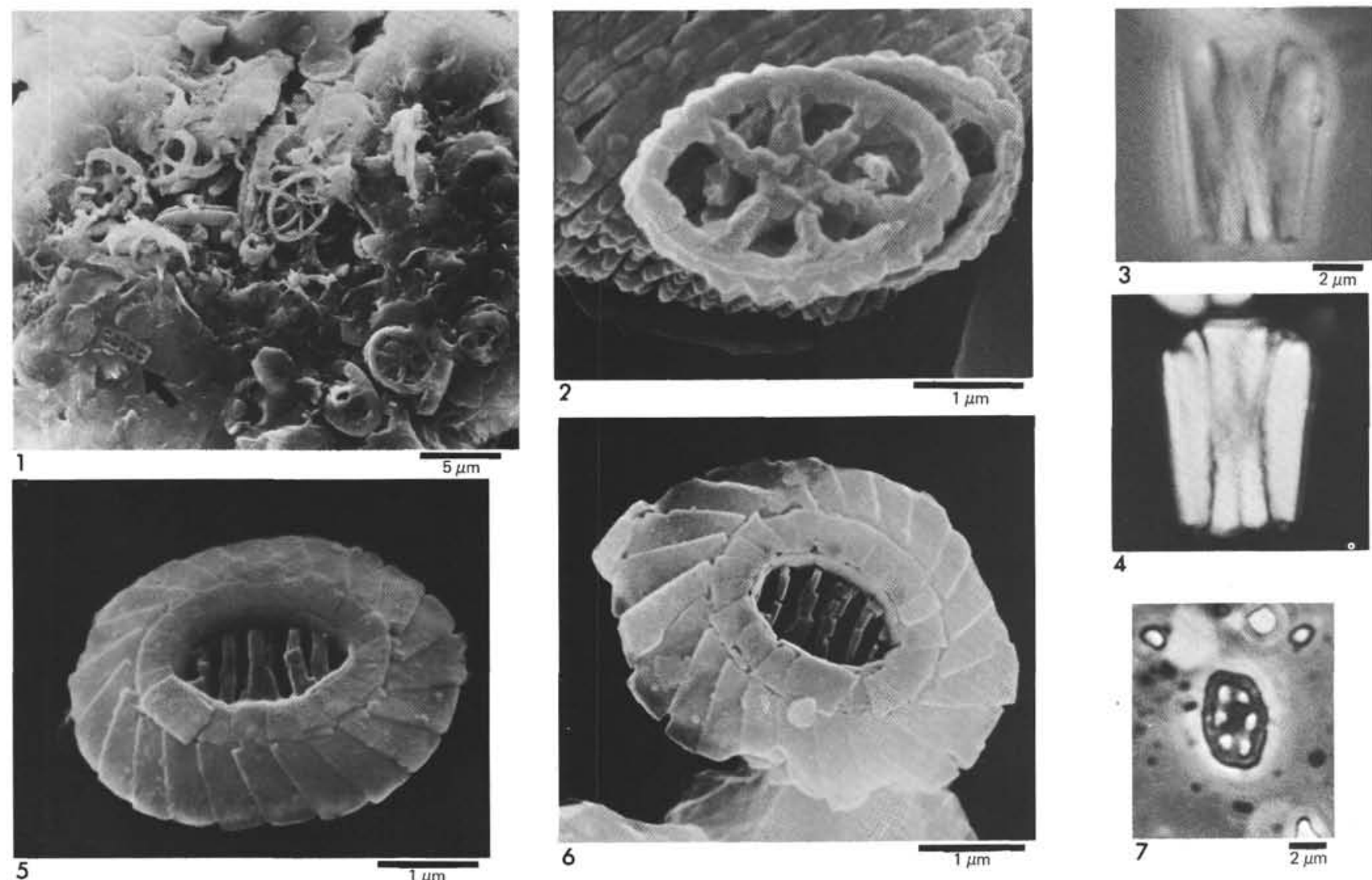

4
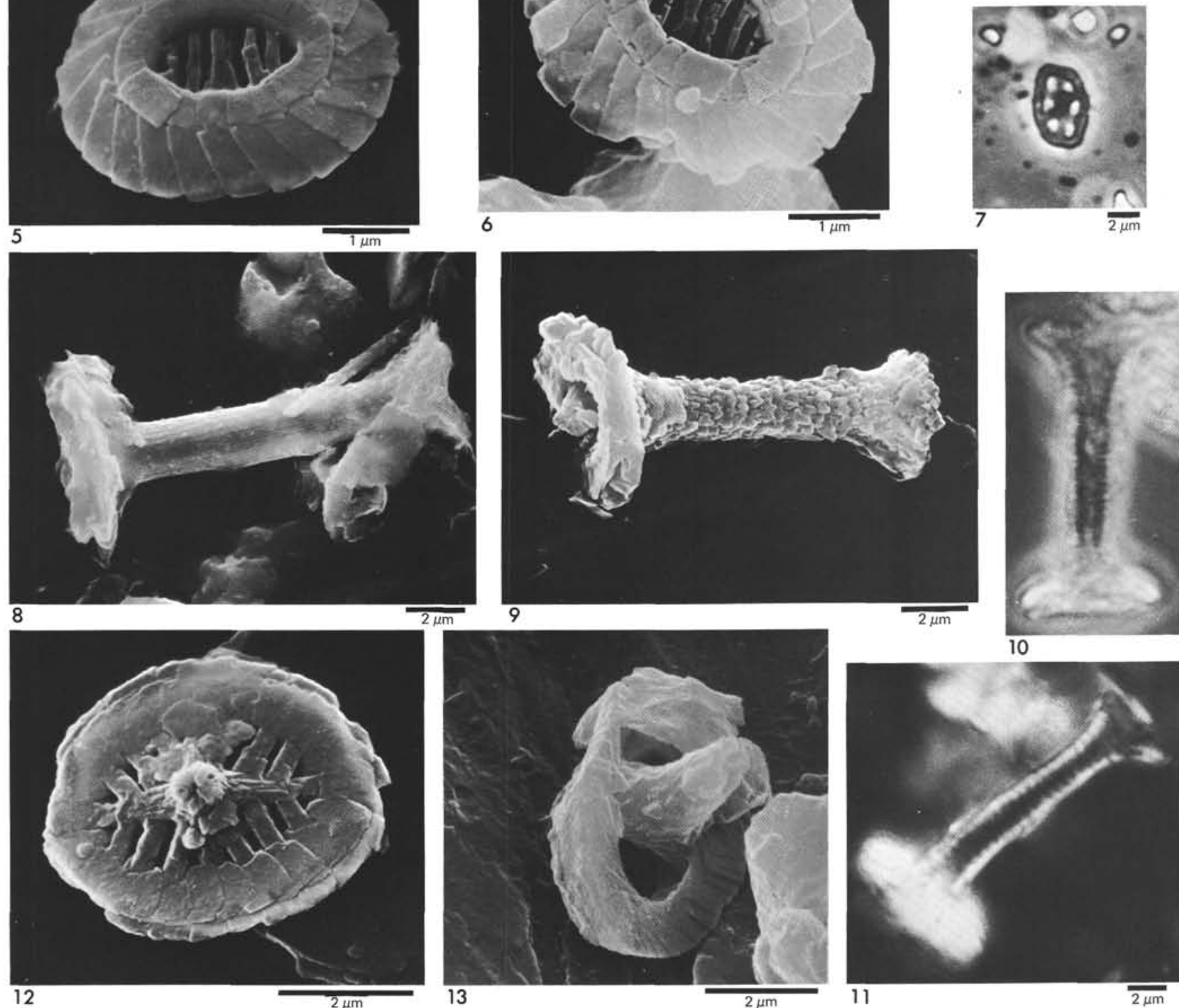


\section{PLATE 8}

Figures 1,4-7 Diloma placinum Wind and Čepek, n. sp. Sample 397A-46-3, 58-59 cm.

1. Scanning electron micrograph; proximal view; holotype USNM 256051.

4,5. Isotype USNM 256052.

4. Phase contrast.

5. Cross-polarized light.

6,7. Isotype USNM 256053.

6. Phase contrast.

7. Cross-polarized light.

Figures 2,3 Diloma primitiva (Worsley, 1971) Wind and Cepek, n. comb.

2. Sample $397 \mathrm{~A}-46-3,58-59 \mathrm{~cm}$.

2. Phase contrast.

3. Cross-polarized light.

Figures 8-17 ?Diloma sp.

8 ,11. Sample 397A-46-3, 58-59 cm. coated specimen.

8. Phase contrast.

9-11. Cross-polarized light.

12-15. Sample 397A-47, CC.

12. Phase contrast.

13-15. Cross-polarized light.

16,17. Sample 47-1, 46-47 cm.

16. Phase contrast.

17. Cross-polarized light.

Figures 18,19 Manivitella pecten Black, 1971. Sample 397A46-3, $58-59 \mathrm{~cm}$.

18. Phase contrast.

19. Cross-polarized light. 
PLATE 8
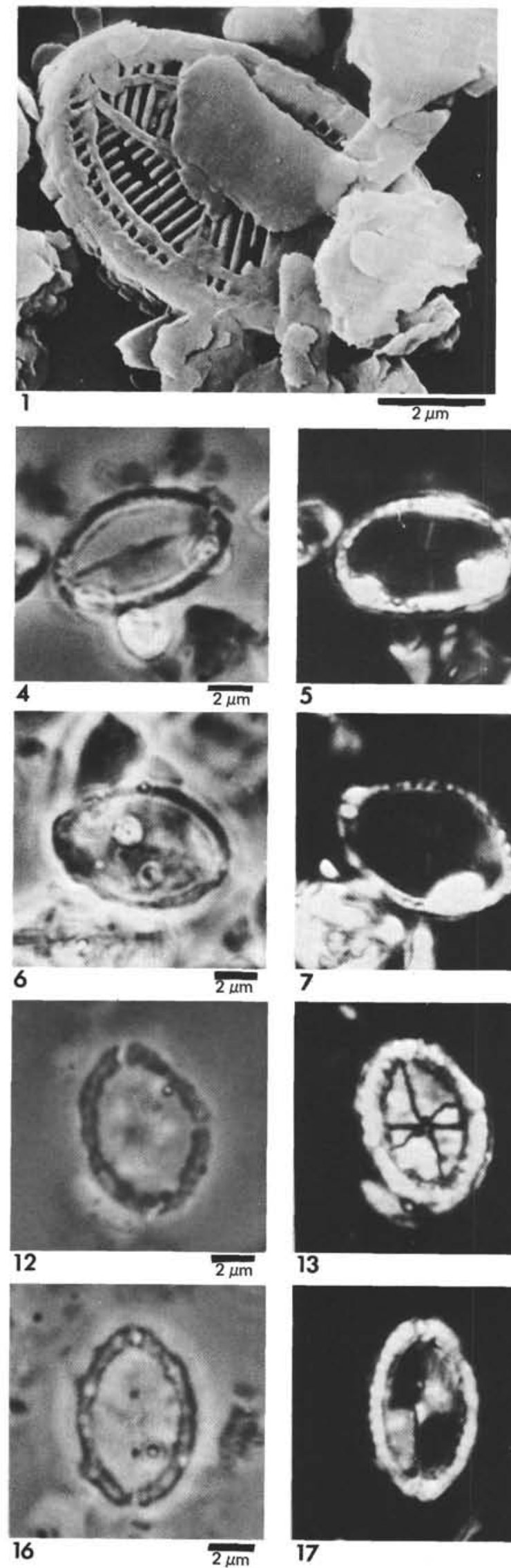
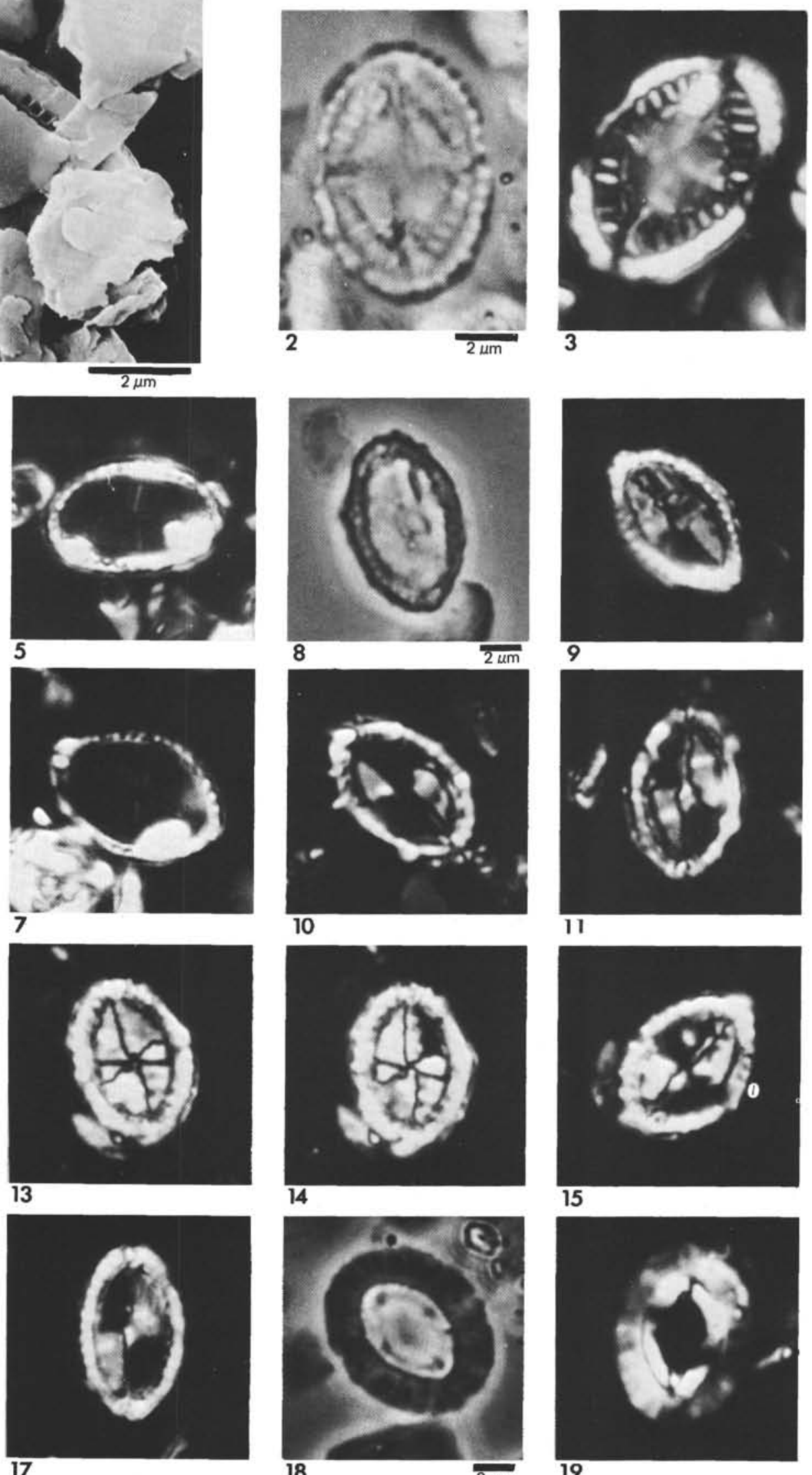

11
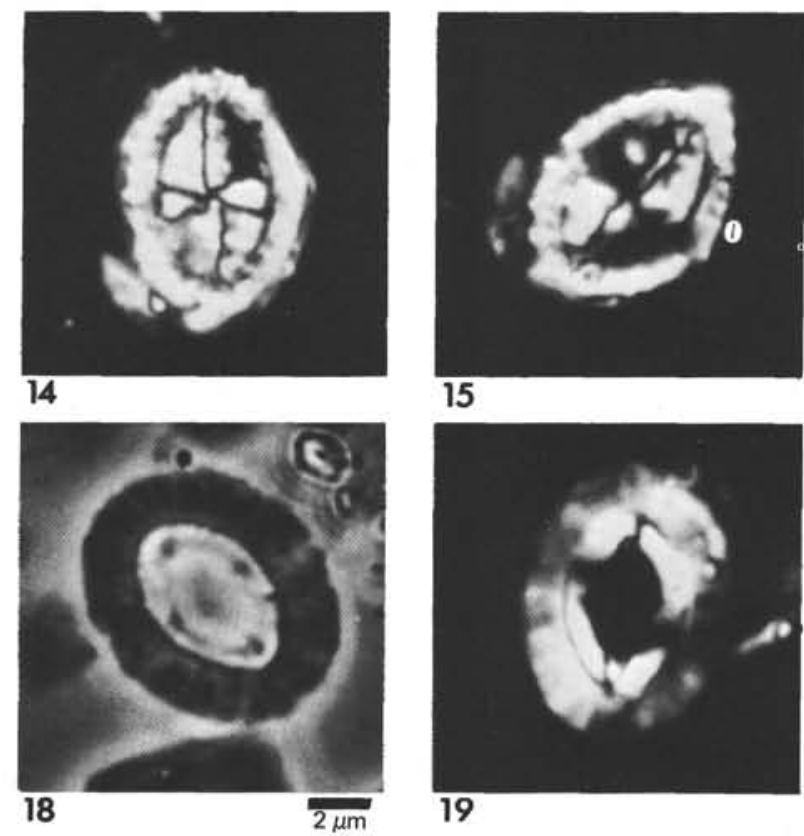

15

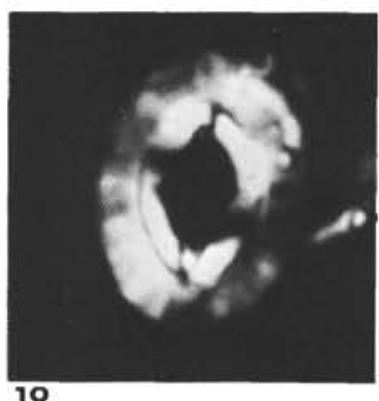




\section{PLATE 9}

Figures 1-3, Lucianorhabdus phlaskus Wind and Cepek, n. sp.

7-10 1-3. Holotype; USNM 256054. Sample 397A$46-3,58-59 \mathrm{~cm}$.

1. Scanning electron micrograph.

2. Coated sample; phase contrast.

3. Cross-polarized light.

7,8. Isotype USNM 256055.

7. Phase contrast.

8. Cross-polarized light.

9,10. Isotype USNM 256056.

9. Phase contrast.

10. Cross-polarized light.

Figures 4-6, Metadoga mercurius Wind and Čepek, n. gen., $11-13,19-20$ n. sp. Sample 397A-46-3, $58-59 \mathrm{~cm}$.

4-6. Holotype USNM 256057.

4. Scanning electron micrograph, lateral view.

5. Phase contrast.

6. Cross-polarized light.

11-13. Aggregate of specimens of Metadoga mercurius Wind and Čepek, n. gen., n. sp.

11. Phase contrast.

12,13. Cross-polarized light.

19,20 . Isotype USNM 256058.

19. Phase contrast.

20. Cross-polarized light.

Figures 14, 15 Lucianorhabdus sp. Sample 397A-41, CC.

14. Phase contrast.

15. Cross-polarized light.

Figure 16 Lucianorhabdus sp. Sample 397A-47, CC. Crosspolarized light.

Figures 17, 18 Lucianorhabdus sp.-(short-stemmed form). Sample $397 \mathrm{~A}-46-3,58-59 \mathrm{~cm}$.

17. Phase contrast.

18. Cross-polarized light. 
PLATE 9

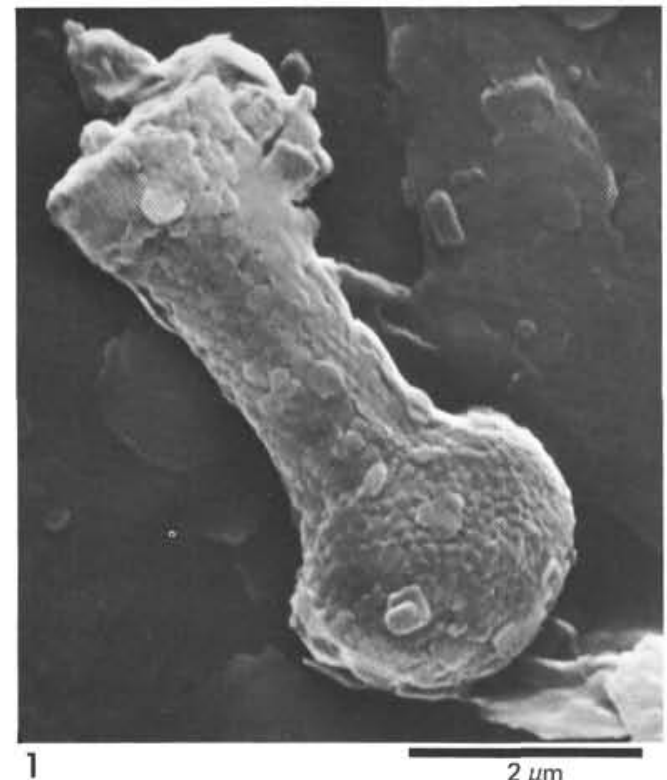

1
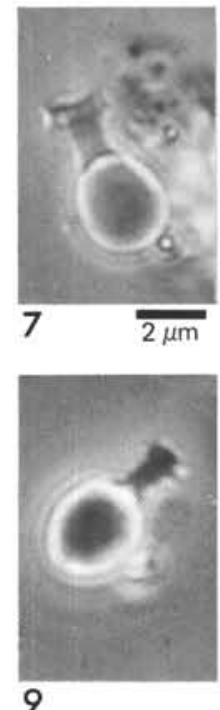

9
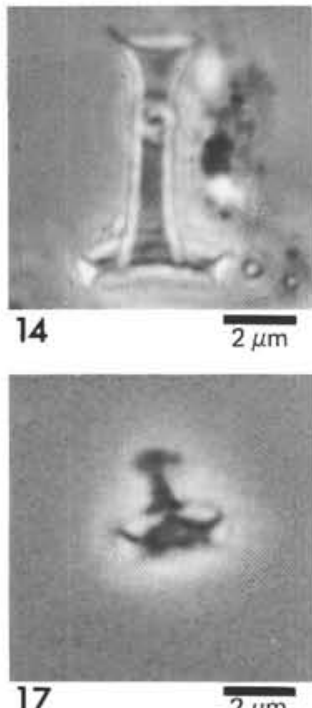

17

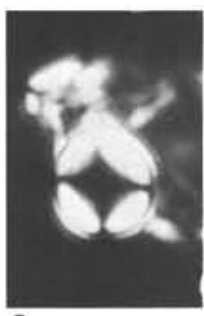

8

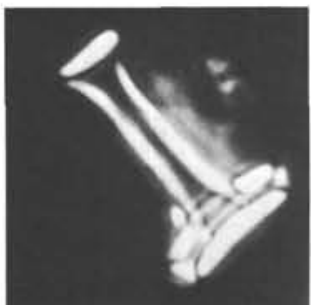

15

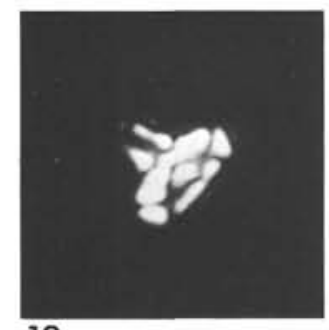

18

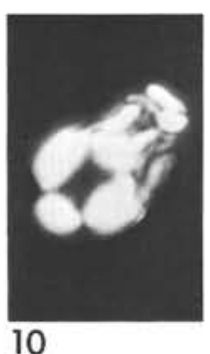

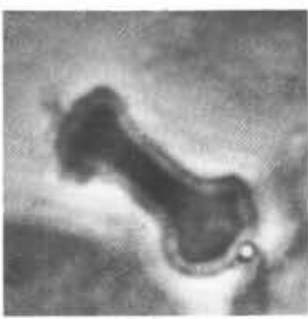

2
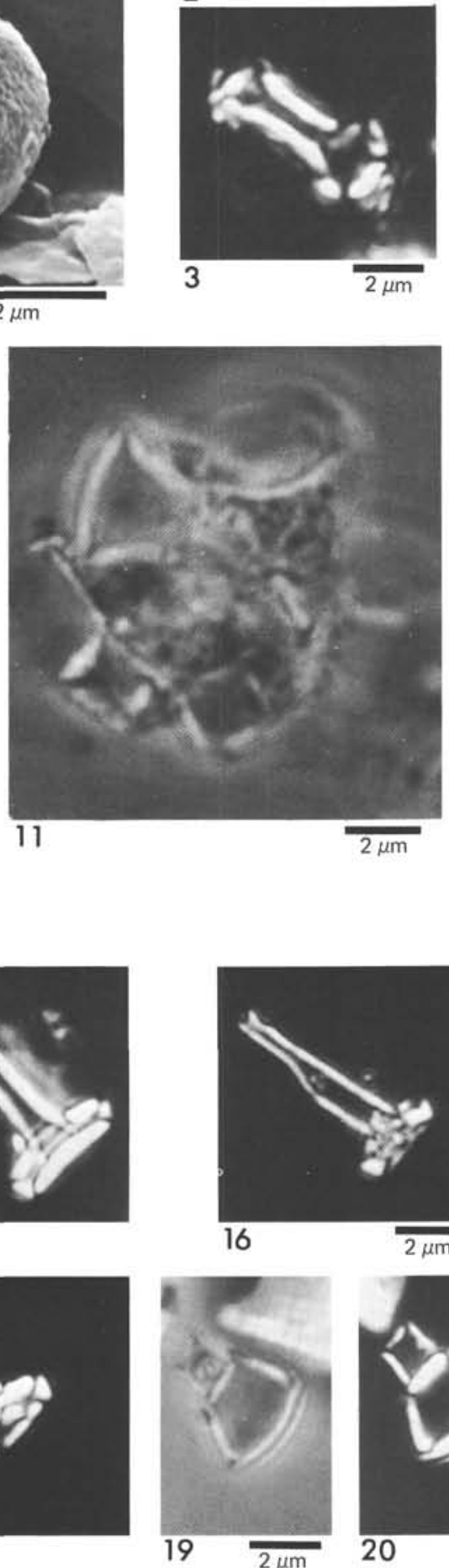

20
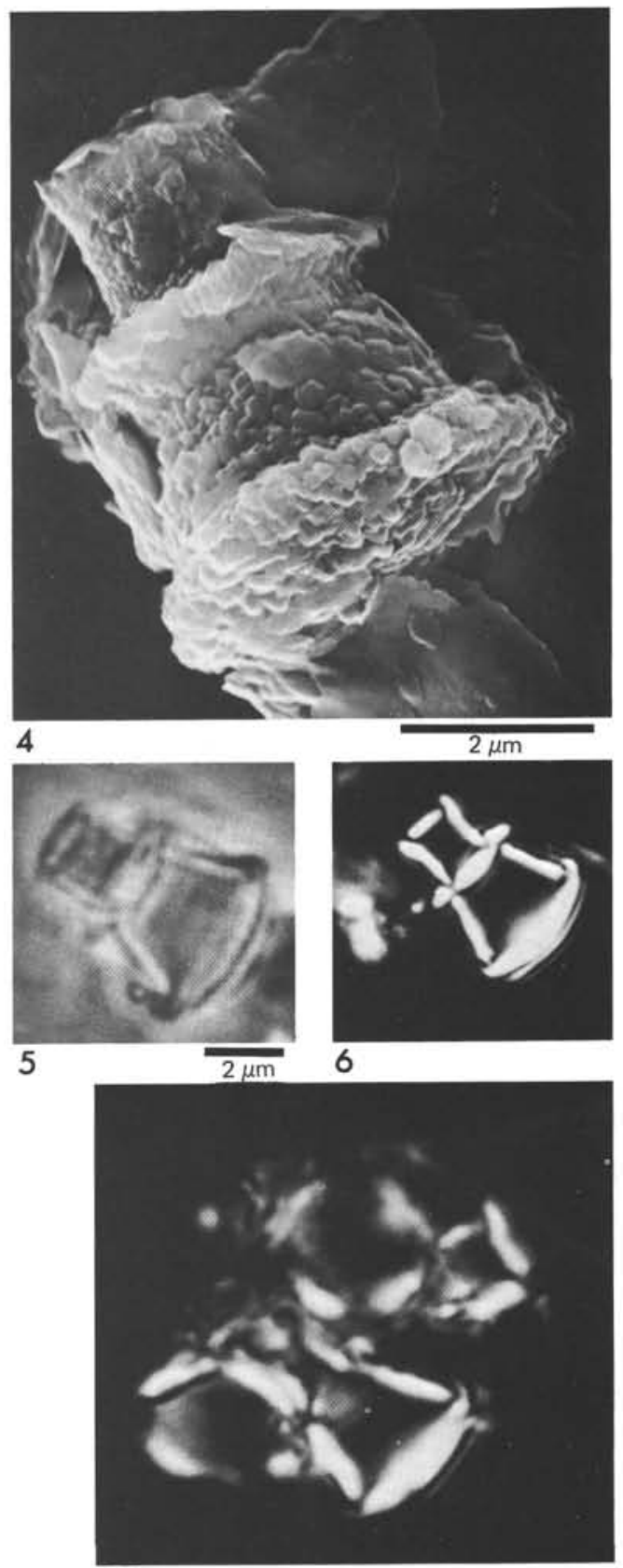

12

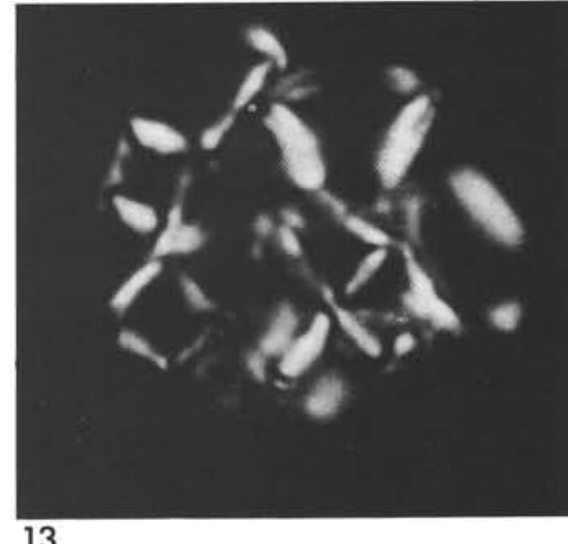




\section{PLATE 10}

Figures 1-4, 8 Reinhardtites fenestratus (Worsley, 1971) Thierstein, 1972. Sample 397A-46-3, 58-59 cm.

1. Phase contrast.

2-4,8. Cross-polarized light.

Figures 5-7 ?Eiffellithus sp.; Sample 397A-46-3, 58-59 cm.

5. Phase contrast.

6,7. Cross-polarized light.

Figures 9-11 ?Eiffellithus sp. Sample 397A-47, CC.

9. Phase contrast.

10-11. Cross-polarized light.

Figures 12, 13 ?Eiffellithus sp. Sample 397A-39, CC.

12. Phase contrast.

13. Cross-polarized light.

Figure 14 Small rhabdolith. Sample 397A-46-3, 58-59 cm; lateral view; scanning electron micrograph.

Figures 15-17 Small rhabdolith. Sample 397A-47, CC.

15. Phase contrast.

16,17. Cross-polarized light.

Figures 18, 19 Small elliptical specimen, probably the base of the rhabdoliths in Figures 14-17. Sample 397A-46-3, $58-59 \mathrm{~cm}$.

18. Phase contrast.

19. Cross-polarized light. 
PLATE 10

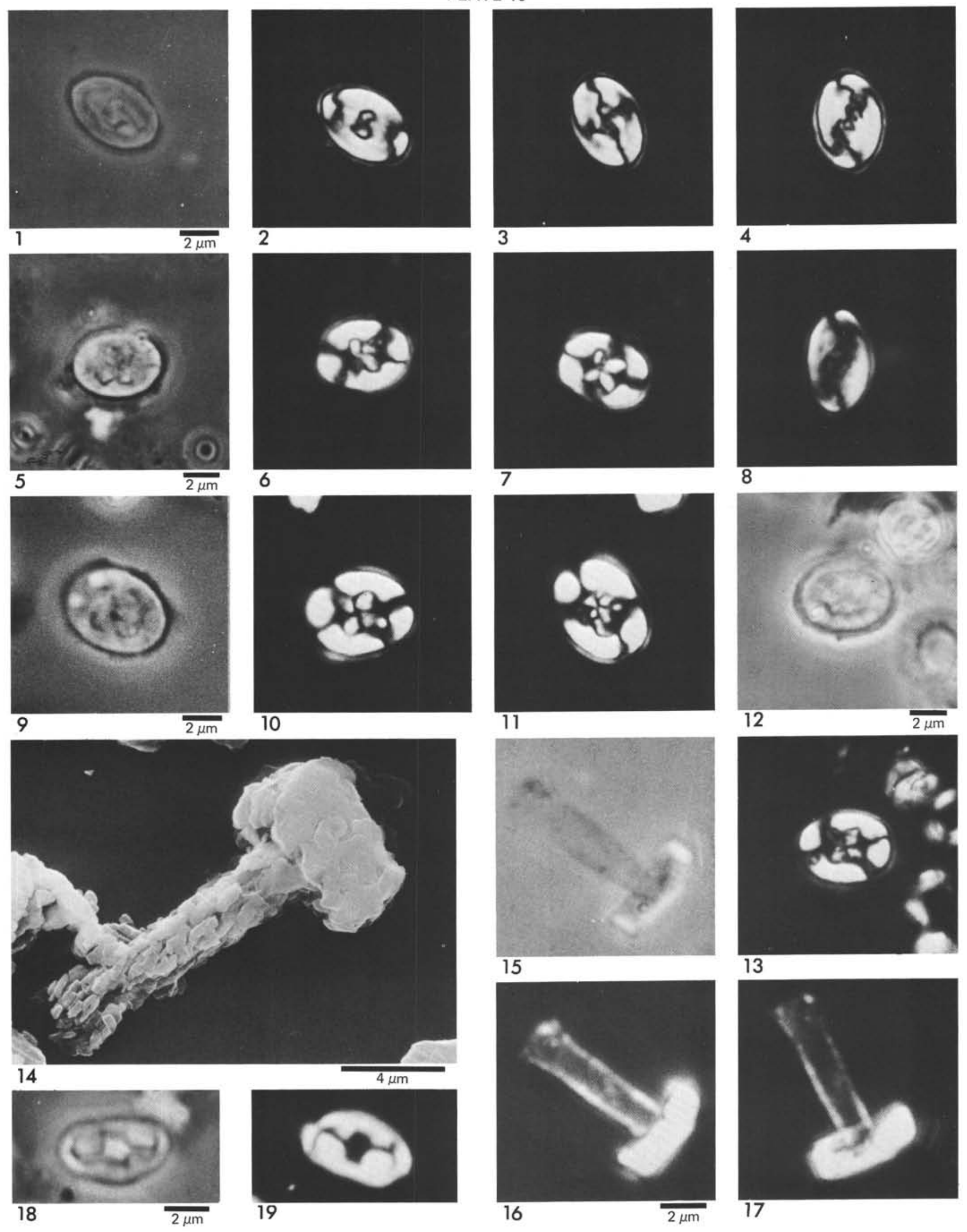




\section{PLATE 11}

Figures 1-4 ?Parhabdolithus sp. lateral view of coated specimen; Sample 397A-46-3, 58-59 cm.

1. Transmitted light.

2. Phase contrast.

3. Cross-polarized light; high focus.

4. Cross-polarized light; low focus.

Figures 5-7 Parhabdolithus judithae Black, 1972; distal view. Sample 397A-46-3, 58-59 cm.

5. Phase contrast; low focus.

6. Cross-polarized light; low focus.

7. Cross-polarized light; high focus.

Figures 8-10 Parhabdolithus swinnertonii (Black, 1971) Wind and Čepek, n. comb.; distal view of coated specimen. Sample 397A-46-3, 58-59 cm.

8. Phase contrast; low focus.

9. Phase contrast; high focus.

10. Cross-polarized light.

Figures 11, 12 Parhabdolithus swinnertonii (Black, 1971) Wind and Čepek, n. comb.; distal view. Sample 397A-47, CC.

11. Phase contrast.

12. Cross-polarized light.

Figures 13, 14 Parhabdolithus swinnertonii (Black, 1971) Wind and Čepek, n. comb.; distal view. Sample 397A-39, CC.

13. Phase contrast.

14. Cross-polarized light.

Figures 15, 16 Parhabdolithus swinnertonii (Black, 1971) Wind and Čepek, n. comb.; distal view. Sample 397 A-47-1, 46-47 cm.

15. Phase contrast.

16. Cross-polarized light.

Figures 17-19 Laguncula dorotheae Black, 1971; lateral view. Sample 397A-46-3, 58-59 cm.

17. Phase contrast; low focus.

18. Phase contrast; medial focus.

19. Cross-polarized light.

Figures 20,21 Laguncula sp. aff. L. dorotheae Black, 1971; lateral view. Sample 397A-46-3, $58-59 \mathrm{~cm}$.

20. Phase contrast.

21. Cross-polarized light. 
PLATE 11
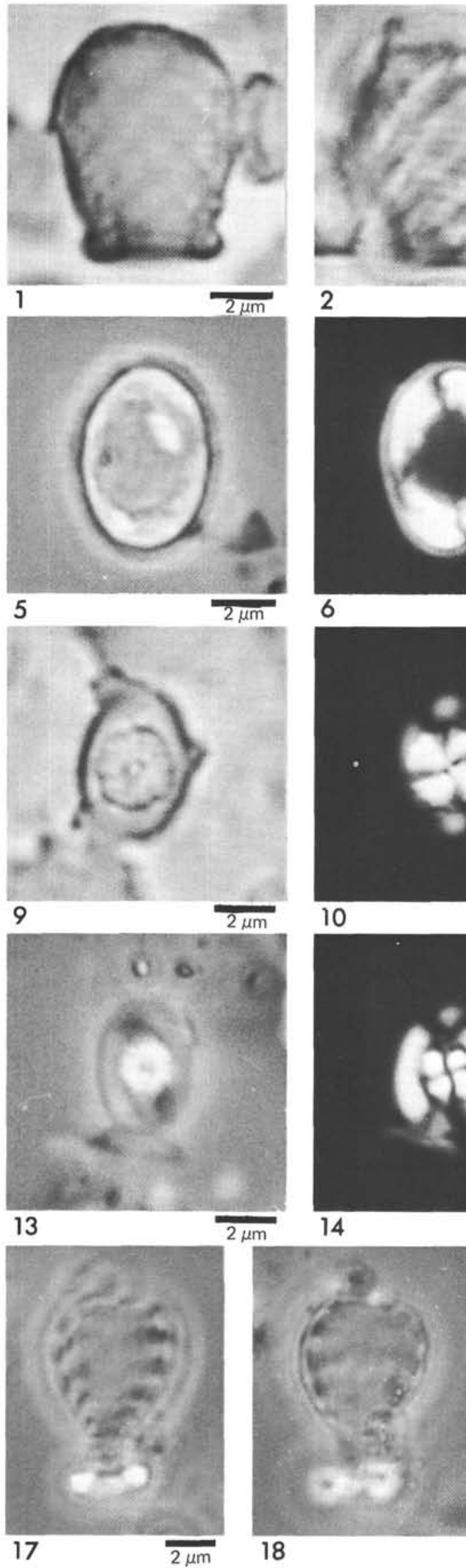

18

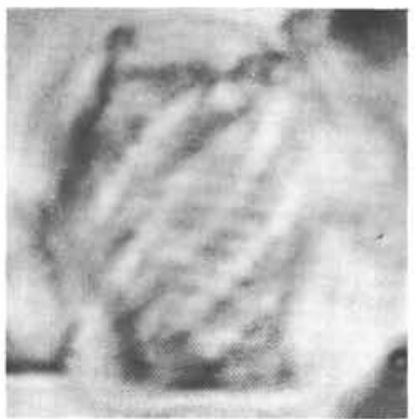

2
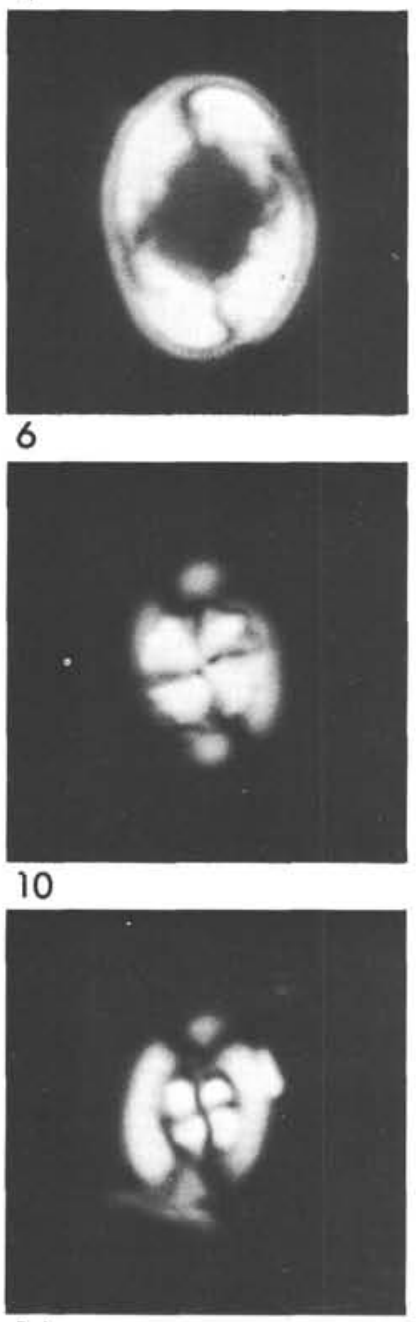

14

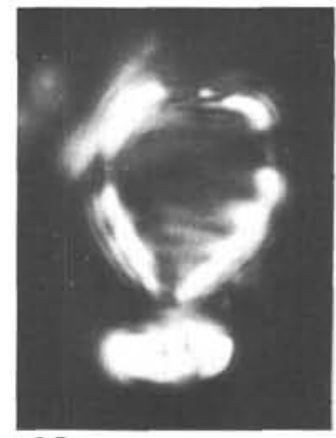

19

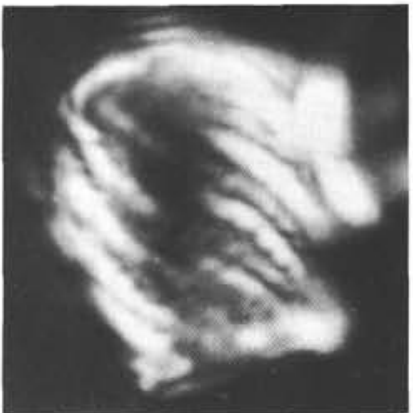

3
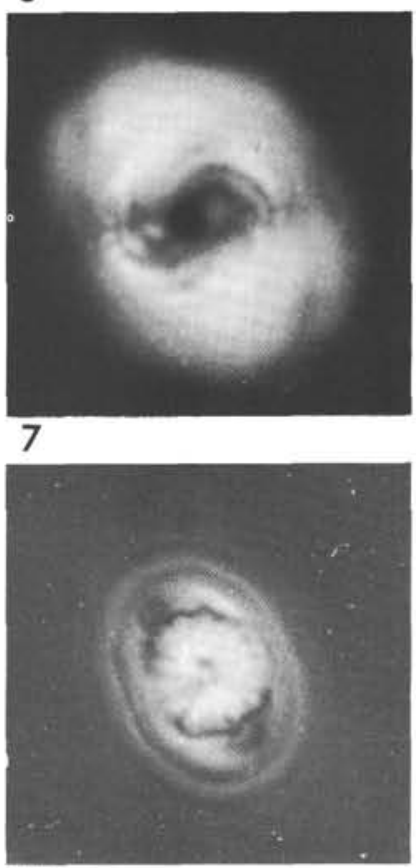

11
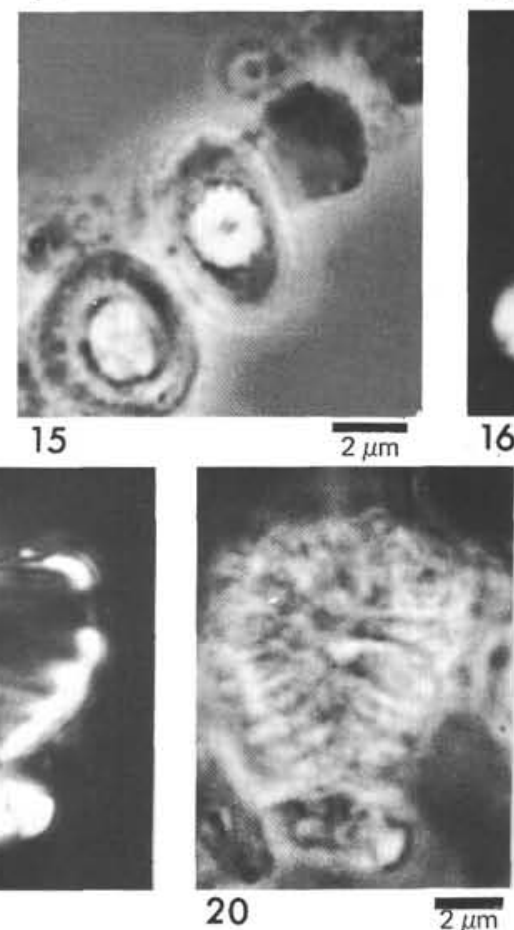
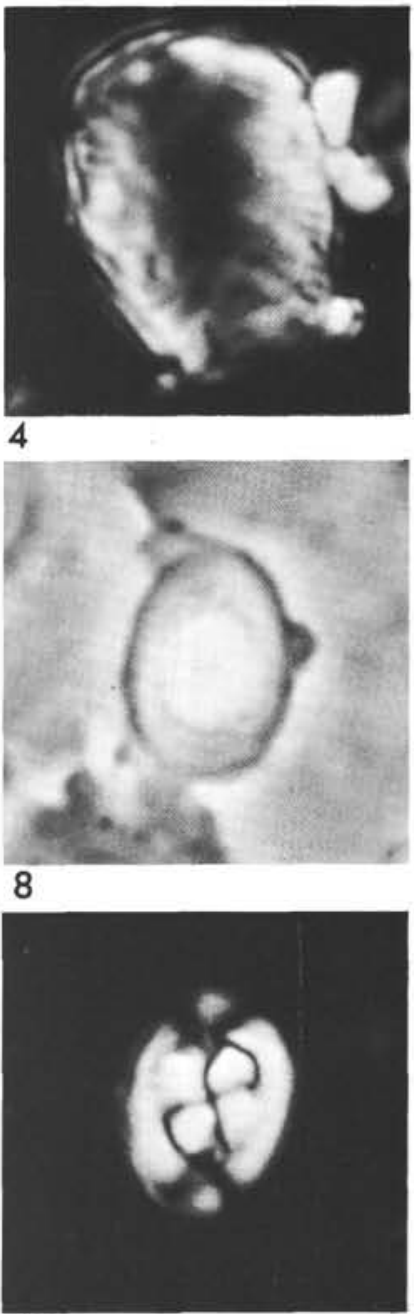

12
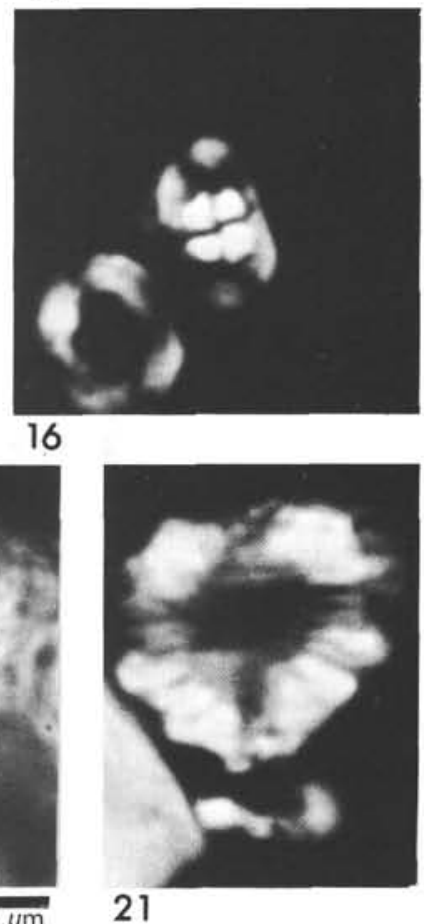